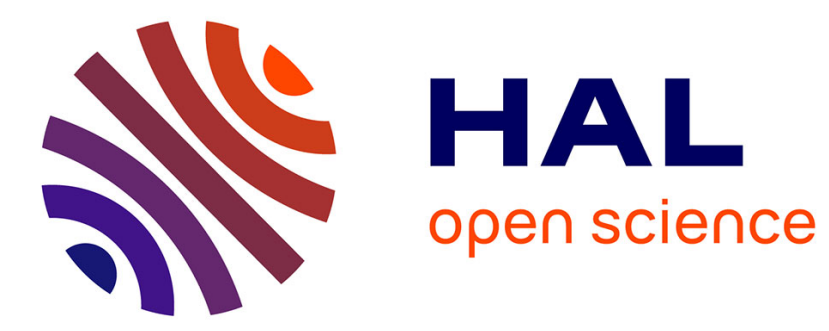

\title{
The singular fate of Genetics in the History of French Biology, 1900-1940
}

\author{
Richard Burian, Jean Gayon, Doris Zallen
}

\section{To cite this version:}

Richard Burian, Jean Gayon, Doris Zallen. The singular fate of Genetics in the History of French Biology, 1900-1940. Journal of the History of Biology, 1988, 21 (3), pp.357-402. 10.1007/BF00144087 . halshs-00775435

\section{HAL Id: halshs-00775435 https://shs.hal.science/halshs-00775435}

Submitted on 16 Apr 2019

HAL is a multi-disciplinary open access archive for the deposit and dissemination of scientific research documents, whether they are published or not. The documents may come from teaching and research institutions in France or abroad, or from public or private research centers.
L'archive ouverte pluridisciplinaire HAL, est destinée au dépôt et à la diffusion de documents scientifiques de niveau recherche, publiés ou non, émanant des établissements d'enseignement et de recherche français ou étrangers, des laboratoires publics ou privés. 


\section{The Singular Fate of Genetics in the History of French Biology, 1900-1940}

RICHARD M. BURIAN*

Department of Philosophy

Virginia Polytechnic Institute and State University

Blacksburg, Virginia 24601

JEAN GAYON

Faculté de lettres et philosophie

Université de Bourgogne

Dijon, France

DORIS ZALLEN

Center for Programs in the Humanilies

Virginia Polytechnic Institute and State University

Blacksburg, Virginia 24601

\section{INTRODUCTION}

It has often been remarked how long it took genetics to penetrate French science. This observation is just. It was not until the late 1940s, for cxample, that genctics appeared in an official university curriculum. At the same time, it is also well known that, as early as the $1940 \mathrm{~s}$, French scientists played an important role at the forefront of genetic research, specifically in work that helped bring about the transition to molecular genetics. These observations seem paradoxical: how could a discipline be both underdeveloped and unrepresented in the curriculum within a particular country while, at the same time, that country's scientists played a central and internationally recognized role in the reshaping of that very discipline? 'l'he present study is intended to shed light on this paradox.

The extreme resistance among French biologists to research programs employing Mendelian genetics, or, at least, to any claims that Mendelian principles are of general biological importance, has been well documented.' This phenomenon is usually accounted for

* The order of the authors is alphabetical and has no other significance.

1. See, for example, D. Buican, Histoire de la génétique et de l'évolutionnisme en France (Paris: Presses Universitaires de France, 1984); or, for a less thorough treatment, the articles by E. Boesiger, E. Mayr, and C. Limoges on the evolutionary synthesis in France in The Evolutionary Synthesis, ed. E. Mayr and W. Provine (Cambridge, Mass.: Harvard University Press, 1980). 
by invoking the tradition of Lamarckism in France. In support of this account, it is often pointed out that French biology did not come to terms with Mendelism until after the success of molecular biology, and that it was only with the advent of molecular biology that retrograde Lamarckism fell into poor repute in France. This way of presenting the matter does, indeed, describe a real dimension of the resistance to genetics in France. Nonetheless, as we shall argue, it provides a totally insufficient explanation of that resistance.

The key to our analysis is the recognition of the importance (in France at least) of non-Mendelian research bearing on the problem of heredity. Accordingly, the central question around which we shall organize our presentation is the following: Given that there was no established Mendelian tradition in France by 1940, from which conceptual and methodological traditions did the French school of molecular biology emerge? Our answer to this question, although still incomplete, reveals that the resistance to Mendelism should also be understood as the result of complex interactions among the diverse and fruitful research traditions that played an important role in the development of molecular biology, especially genetics, in France.

To put our position briefly: the country of Lamarck was also the country of Claude Bernard and Louis Pasteur. For more than a century, the ideals of biological work in France were set by physiology (understood as the study of the specific physico-chemical mechanisms found in living organisms), causal embryology (understood as an examination of the effects of various experimental manipulations and perturbations of developing embryos), and microbiology. This triple context provides the setting within which the French school of molecular biology came into being.

We shall show that the dominance of the physiological, embryological, and microbiological traditions in France is central to a proper explanation of the anti-Mendelism that characterized French biology before World War II. To support this claim we will exhibit (in section 2 below) some of the deep connections between the extremist opposition to Mendelian genetics and the major features of several exemplary programs of experimental research in physiology, embryology, and microbiology undertaken in the twenties and the thirties. We will also show that these very same research programs made decisive contributions to the emergence of the future molecular biology.

The story, then, is one of ironies. The same matrix of biological philosophy that served as a source of polemical arguments against Mendelism, many of them ill-grounded, also provided essential 
components of the framework that played a major role in the international transformation of Mendelian into molecular genetics. Unlike their Anglo-American counterparts, French biologists uniformly insisted that the analysis of heredity should exhibit features like those found in Bernardian physiology and/or Pasteurian microbiology. Additionally, French biologists were unwilling to set aside, even temporarily (as was done, for example, by the Morgan school in the United States ${ }^{2}$ ), the requirement that an acceptable theory of heredity be reconciled with work in causal embryology. Adherence to these background commitments explains why and how French anti-Mendelism ultimately yielded a tradition of research into heredity independent of those traditions, found elsewhere, that were based on Mendelian methods.

We shall take for granted in the following pages that there was a real explosion of genetics in France in the late 1940s and that it helped establish the new discipline/tradition of molecular genetics. (For present purposes we define molecular genetics by the utilization of biophysical and biochemical methods, initially on microorganisms, to obtain an account at the molecular level of the materials transmitted in heredity and of the mechanisms by which those transmitted materials control the traits of the organisms in which they occur.) We will also take for granted two distinguishing characteristics of the French school: an interest in questions of physiology rather than questions of structure, and a fruitful, though perhaps obsessional, concern with cytoplasmic or, more generally, "non-Mendelian" inheritance.

Our principal objectives in this essay are to reexamine the problem of the reception of Mendelian genetics and the development of Mendelian research in France from 1900 to 1940, and to examine the non-Mendelian methods and foci of research that emerged in the field of heredity between the two wars. We will then show that these methods and research interests helped pave the way for the French school of molecular genetics.

2. See, for example, the last paragraph of the chapter on "The Factorial Hypothesis" of T. H. Morgan, A. H. Sturtevant, H. J. Muller, and C. B. Bridges, The Mechanism of Mendelian Heredity (New York: Henry Holt, 1915 and 1922), in support of the claim that "[a]though Mendel's law does not explain the phenomena of development, and does not pretend to explain them, it stands as a scientific explanation of heredity, because it fulfills all the requirements of any causal explanation" (quoted from the revised ed., p. 281). 


\section{TIIE ENTRY OF MENDELISM INTO FRANCE FROM 1900 TO 1940}

It is important to ask what French biologists knew about Mendelism and when, how it was taught in the relevant institutions of higher learning, and how it affected the research of those biologists who had an interest in heredity. We must also face the anti-Mendelian polemics that were encountered both within French biology and around its fringes, if for no other reason than because of their extreme character and their notoriety. To accomplish these objectives, we have (1) examined the periodicals that were most representative of the biological climate from 1900 to 1940: Comptes rendus de l'Académie des Sciences, Comptes rendus de la Société de Biologie, Bulletin biologique de la France et de la Belgique, ${ }^{3}$ and the Année Biologique, plus a sampling of other journals; (2) reviewed popular books and textbooks discussing genetics in the French language; (3) undertaken biographical investigations of key individuals, including Lucien Cuénot, Boris Ephrussi, Emile Guyénot, Philippe L'Héritier, André Lwoff, Georges Teissier, and Eugène and Élie Wollman; and finally, (4) interviewed some of the remaining individuals ${ }^{4}$ who can provide first-hand testimony regarding events of the latter part of the period with which we are concerned.

The usual presentation of the resistance to Mendelism is Manichæan: what occurred was a forty-year fight of the forces of light against those of darkness, with a small number of enlightened individuals battling against massive retrograde forces. This vision is at least partly confirmed in various documents produced during the period between the two world wars. It represents an aspect of reality that cannot be neglected. But our analysis of the documents reveals a more complex situation. There is, for example, every indication that Mendelian doctrines were rapidly and securely diffused in the learned biological community immediately after the turn of the century; Mendelism was evaluated from a variety of angles and was the object of considerable ongoing attention, not all of it unfavorable. And yet this does not alter the fact that Mendelian research was extremely rare among French biologists during the entire first half of the century.

3. Until 1917 called Bulletin scientifique de la France et de la Belgique.

4. The most important of these are Ph. L'Héritier, A. Tetry, and R. Wurmser. We also intervicwed a number of figures from the next gencration, including $J$. Beisson, G. Cohen, J. M. Goux, C. Petit, P. Slonimski, M. Weiss, Élie Wollman, and a few Americans who spent a year or more in French laboratories in the 1940 s or 1950 s. 
A synthesis of these elements shows that many witnesses tell the story as one of extreme anti-Mendelian polemics, that the principal figures of French biology were well informed about developments within the new science, and that most of them, including those who defended genetics, did not practice it. On the basis of these considerations, together with an analysis of the specific content of the literature of the day, we shall argue that French biologists generally viewed themselves as referees or judges of the Mendelian tradition, but not as agents in the development of Mendelism.

To support this account of the matter, we shall examine three separate aspects of the reception of Mendelism in France: (1) the diffusion of Mendelism, and later of chromosomal genetics, within the ordinary channels of information utilized by the biological community and the learned public; (2) the entry of Mendelism into the curriculum; and (3) the experimental and theoretical research produced by Mendelism. Each of these three aspects of the reception of Mendelism tells a strikingly different story - a fact that demonstrates certain peculiarities of French biology, some of which will prove of importance in later parts of this article.

\subsection{The Diffusion of Mendelism among French Biologists}

In the period immediately after the turn of the century, reports on Mendelian genetics were widely, rapidly, and thoroughly diffused within the French-speaking biological community. There was considerable pride that events pertinent to the rediscovery and development of Mendelism took place on French soil. Among these was the very first article officially presenting Mendel's laws (although without explicit mention of Mendel), published in French by Hugo de Vries in 1900 in the Comptes rendus de l'Académie des Sciences.5 During the decade 1900-1911, Cuénot's research on the inheritance of pigmentation and of cancer in mice was published in the most prestigious French journals. In 1911, Cuénot received the Cuvier Prize of the French

5. H. de Vries, "Sur la loi de disjonction de hybrides," Comp. Rend. Acad. Sci., 130 (1900), 845-847. See also idem: "Sur les unités des caractères spécifiques," Rev. Gén. Bot, 12 (1900), 83-90; "Das Spaltungsgesetz der Bastarde," Ber. deut. botan. Gesell., 18 (1900), 83-90; and "La loi Mendel et les caractères constants des hybrides," Comp. Rend. Acad. Sci., 136 (1903), $321-323$.

6. See L. Cuénot, "La loi de Mendel et l'hérédité de la pigmentation chez les souris," Arch. Zool. Exp. Gén., 3rd ser. 10 (1902), 27-30; "Sur quelques applications de la loi de Mendel," Comp. Rend. Soc. Biol., 4 (1902), 397-398; 
Academy of Sciences; the award citation made special mention of his work on Mendel's laws.

During this period, there were prompt and extensive reports on the development of Mendelism outside France. As early as 1900, L'Année Biologique provided exhaustive and accurate reviews of the principal developments within Mendelian genetics. This journal, founded by Yves Delage in 1895, was the first Frenchlanguage journal specifically devoted to biological abstracts and reviews. ${ }^{8}$ Internationally, it may have been the first review journal to focus on articles and books of interest for "the great problems of general biology." For half a century, L'Année Biologique remained an incomparable tool, frequently used by nearly all French biologists.

An examination of the articles touching on heredity in L'Année from 1900 to 1914 demonstrates that the early Mendelian work was carefully reviewed, with a clear recognition of its importance.

"Les recherches expérimentales sur l'hérédité," Ann. Biol., 7 (1902), 58-77; "L'hérédité de la pigmentation chez les souris (2ème note)," Arch. Zool. Exp. Gén., 4th ser., I (1903), 33-41; "Hérédité de la pigmentation chez les Souris noires," Comp. Rend. Soc. Biol., 5 (1903), 298-299; "Transmission héréditaire dc pigmentation par les Souris albinos," ibid., pp. 299-301; "Hypothèse sur l'hérédité des couleurs dans le croisement des Souris noires, grises et blanches," ibid., pp. 301-302; "L'hérédité de la pigmentation chez les Souris (3ème note)," Arch. Zool. Exp. Gén., 4th ser., 2 (1904), 45-56; "Un paradoxe héréditaire chez les Souris," Comp. Rend. Soc. Biol., 6 (1904), 1050-52; "Les recherches expérimentales sur l'hérédité mendélienne." Rev. Gén. Sci. Pures Appl., 15 (1904), 303-310; "Les races pures et leurs combinaisons chez les Souris (4ème notc)," Arch. Zool. Exp. Gén., 4th ser., 3 (1905), 123-132; "L'hérédité de la pigmentation chez les Souris (5ème note)," ibid., 6 (1907), 1-14; "Sur quelques anomalies apparentes des proportions mendéliennes (6ème note)," ibid., 7 (1908), 7-15; "Les déterminants de la couleur chez les Souris: Étude comparative (7ème note)," ibid., 9 (1911), 40-55; "L'hérédité chez les Souris," Verhandl. naturf. Ver. Brünn, 49 (1911), 1-9. For an English article, see L. Cuénot, "Heredity," Ann. Rep. Smiths. Inst., 1906, pp. 335-344. For references to Cuénot's work on the inheritance of cancer in micc, see below, n. 38 .

7. See the report in Comp. Rend. Acad. Sci., 153 (1911), 1337-42.

8. The complete title is L'Année Biologique. Comptes rendus annuels des travaux de Biologie générale. The first volume (imprint 1895) was published in 1897.

9. In the preface to the first volume, Delage considered the new periodical to be "the natural consequence" of his book on heredity and the major problems of general hiolngy (I a structure du protoplasma et les théories sur l'hérédité et les grands problèmes de la biologie générale (Paris: Reinwald \& Cie, 1895|):

Les personnes à qui ce livre est resté étranger pourront se demander s'il était bien nécessaire de fonder un nouveau recueil d'analyses et si nous n'avions pas assez de nombreux périodiques de ce genre qui existent dans diverses langues. 
De Vries's note in the Comptes rendus de l'Académie des Sciences, ${ }^{10}$ for example, is covered twice in the volume for 1900 . Delage devoted a page to it in the annual overview with which each volume was begun; he labeled it "the very remarkable study by de Vries on the laws of hybridization" and summarized the quantitative results precisely. " Cuénot also provided a long abstract of the same paper. ${ }^{12}$ In 1901, papers of William Bateson, Carl Correns, Erich Tschermak von Seysenègg, and de Vries were extensively reviewed, with clear explications of the Mendelian vocabulary. In 1902-1903, one finds reviews of work by Bateson, W. E. Castle, Correns, Cuénot, A. D. Darbishire, Leonard Doncaster, Valentin Haecker, de Vries, and E. B. Wilson. More significant, perhaps, was the "general review" on "Experimental Research on Heredity," written by Cuénot for the 1902 volume. ${ }^{1.3}$ Three or four such general reviews were published annually on particularly active and promising biological topics - precisely those topics that the editor felt should not be ignored by any biologist. Cuénot's article and critical bibliography made it impossible for any serious French-speaking biologist with an interest in heredity to ignore the experimental basis of Mendelism.

For our purposes, the important point is that reliable information about Mendelism was easily available in French from the most obvious, routinely employed source. It is perhaps important to add that, in spite of some claims to the contrary, French research scientists at the turn of the century commonly read German and/or English. Bibliographies and frequent discussions of original articles in those languages provide solid evidence in this regard.

One objection that might be raised to the evidence provided above is that a journal of reviews and abstracts does not provide a faithful image of the actual diffusion of Mendelism within the

Nous pourrions répondre qu'il n'en existait pas en français, et c'est un fait à prendre en considération. Mais nous n'aurions pas cependant trouvé là une raison suffisante: ce qui nous a décidé, c'est qu'on ne trouve pas actuellement nulle part, dans aucune langue, les renseignements qu'il doit contenir.

II diffère en effet des ouvrages similaires par son but que son titre n'indique qu'à moitié et qui est non pas tant d'analyser ce qui a trait aux faits généraux de la biologie que de trier ce qui, dans la biologie générale, víse l'explication des phénomènes. (Ann. Biol., 1 (1895). II)

10. See note 5 above.

11. Ann. Biol., 4 (1899-1900), 40-41.

12. Ann. Biol., 4 (1899-1900), 341-342.

13. L. Cuénot, "Les recherches expérimentales sur l'hérédité." Ann. Biol, 7 (1902), 58-77. 
French biological community at the beginning of the century. This objection presents a difficult question. We grant the importance of distinguishing between the amount of information available and the acceptance of Mendelian claims. As we shall see below in section 1.3, Cuénot was the only French biologist who consistently employed Mendelian methodology before World War I. But many other workers who were concerned with heredity during this period took Mendelism seriously, even though they worked on a different basis. They often referred to Mendelism, and their writings show that even if it was not integrated into their experimental practice, it was known, understood, and widely discussed. Consider, for instance, the Bulletin scientifique de la France et de la Belgique before World War I. This journal, founded by Alfred Giard, was a bastion of neo-Lamarckism before becoming an even stronger bastion of anti-Mendelism under the influence of Étienne Rabaud. Nonetheless, it was this journal that published the first French translations of Mendel's memoirs on hybridization in 1907. ${ }^{1+}$ Similarly, in 1912 Rabaud asked Arend Hagedoorn to write an article on "Genetic Factors in the Development of Organisms." ${ }^{5}$ Rabaud's response to Hagedoorn, "Lamarckism and Mendelism," reveals his failure to comprehend Mendelism as well as his refusal to accept it, but it also shows that he was fully aware of the extraordinary flourishing of Mendelian studies in America. ${ }^{16}$ Indeed, he complains (somewhat disingenuously, we suspect) of "the very inferior quality" of the huge number of studies on heredity coming from America. Rabaud, moreover, insistently supported the experimental work of A. Delcourt and Guyénot on Drosophila (about which see below, section 1.3), fostering the publication of a series of papers by the two young scholars in the Bulletin $^{17}$ as well as other prestigious journals (Comptes rendus de l'Académie des Sciences and Comptes rendus de la Société de Biologie), and even going so far as to keep their flies for them during World War I. This work, although initially openly anti-

14. G. Mendel: "Recherches sur les hybrides végétaux" and "Sur quelques hybrides d'Hicracium obtenus par fécondation artificielle," Bull. Sci. Fr. Belg., 41 (1907), 401-413, 414-419.

15. A. Hagedoorn, "Les facteurs génétiques dans le développement des organismes," Bull. Sci. Fr. Belg., 46 (1912), 101-122.

16. E. Rabaud, "Lamarckisme et Mendélisme," ibid., pp. 123-138.

17. A. Delcourt and E. Guyénot, "Génétique et milieu. Nécessité de la détermination des conditions; sa possibilité chez les drosophiles. Technique," Bull. Sci. Fr. Belg., 45 (1911), 219-322; E. Guyénot, "Action des rayons U.V. sur Drosophila ampelophila Löw," ibid., 48 (1914), 160-169; and E. Guyénot, "Recherches expérimentales sur la vie d'un organisme en fonction du milieu," ibid., 51 (1917), 1-330. 
Mendelian, provides a solid indication of the extent to which Mendelism was known and understood, even if it was not accepted or practiced.

Perhaps we should add that an International Congress of Genetics, ostensibly the fourth, ${ }^{18}$ was held in Paris in 1911 at the instigation of the de Vilmorin family of plant breeders, an indication that there was a receptive climate for genetics as of that date. The congress yielded a number of original contributions (by Bateson, Wilhelm Johannsen, R. C. Punnett, and Tschermak) that were made available in French. Adding the original contributions in French by such figures as Cuénot, Frans Alfons Janssens, and de Vries ${ }^{19}$ to these, there is a small but significant body of original work in Mendelian genetics published during the first dozen years of the century.

This evidence amply justifies our assertion that the initial phases of Mendelian research entered thoroughly into the routine communication network of the French biological community during the first two decades of this century.

\subsection{The Teaching of Mendelism}

How and when did Mendelian genetics enter into the curriculum in France? A clear answer to this question is needed in order to interpret the facts of diffusion that we have just mentioned, for what is taught by one generation to its students determines the traditions in which the following generation will work. At stake are the models, methods, and problems that will seem natural to working biologists. When a certain sort of knowledge is not

18. Although the official English title was "Fourth International Conference [not Congress| on Genetics," the first three (1899, 1902, and 1906) were called "Conferences on Hybridisation and Cross-Breeding." In the Proceedings, the third was renamed as the "Third International Conference on GENETICS; Hybridization (the Cross-Breeding of Genera or Species), The Cross-Breeding of Varieties, and General Plant Breeding" - thanks to a speech by Bateson in which he argued for his newly coined term, "genetics," as a means of reflecting the revolution occasioned by the rediscovery of Mendelism and the allied changes in the study of heredity. In spite of the numbering of the Paris conference, therefore, it could well be considered as the first or second international congress of genetics. This surely should be taken into account in evaluating the reception of the new science among French biologists. We are grateful to William B. Provine for calling the early history of these congresses to our attention and providing us with information about them.

19. For de Vries and Cuénot, see above, notes 5 and 6. For Janssens, see "La théorie de la chiasmatypie, nouvelle interpretation des cinèses de maturation," Cellule, 25 (1909), 389-406. 
transmitted to the next generation in its formative years, that knowledge will remain marginal.

This is exactly what happened to genetics in France. The failure of genetics to enter into the curriculum meant that it was not fully assimilated, that it had the status of an alien paradigm. The evidence in support of this claim is clear and decisive.

Let us first consider the teaching programs in the universities. The first chair of genetics was created for Boris Ephrussi at the Sorbonne after World War II, ${ }^{211}$ followed shortly by the first "Certificate" of Genetics; this was the first formal program in which one could obtain credit for a program of study specifically in genetics. It is, of course, important to ask whether there was any teaching of genetics under another label before World War II. Most of the people we have interviewed answer with a categorical negative. This is, however, not entirely correct; small curricular units on genetics were often included within the framework of the Certificate of General Biology in a portion of that program dealing with the nature of species and with the problems of adaptation and evolution. Such units were taught by Cuénot in Nancy, Maurice Caullery in the Sorbonne, and Louis Blaringhem in the École Normale Supérieure in the twenties. ${ }^{21}$ In all of these cases, the teaching was largely theoretical and, given the French traditions in evolutionary theory, highly polemical as well.

$\Lambda$ further piece of evidence regarding the failure of Mendelism to be absorbed into the curriculum is provided by an examination of doctoral theses in biology. The very first doctoral thesis in genetics was published in 1937 by Philippe L'Héritier. ${ }^{22}$ It concerned quantitative genetics and was based on techniques and ideas deriving in part from L'Héritier's studies in America during the year 1932 .

20. Compared to some countries this is quite late. In Germany, for instance, Erwin Baur became Professor of Genetics at the Landwirtschaftliche Hochschule in Berlin in 1913 and headed the Institut für Vererbungsforschung from 1921 on in Berlin-Dahlem, while in Russia Aleksandr Serebrovsky was named to a chair of gcnetics at Moscow in 1930. A quick glance at Provine's table of centers of genetic research in the mid-twenties (pp. 52-53 of "Genetics," in Mayr and Provine, Evolutionary Synthesis, [above, n.1] provides ample corroboration of the institutional delays in France.

21. Our information about Cuénot and Blaringhem comes from interviews with A. Tetry and J. M. Goux, respectively. Regarding Caullery, see Ph. L'Héritier, "Souvenirs d'un généticien," Rev. Synth., 103-104 (1981), 336.

22. Ph. L'Héritier, Étude de variations quantitatives au sein d'un espèce: Drosophila melanogaster [These de doctorat es sciences] (Paris: Éditions des Archives de Zoologie expérimentale, 1937). See also our account of Guyénot's thesis in section 1.3 below. 
An examination of all of the textbooks published before 1940 provides a more precise indication of the failure of the French biological establishment to train the new generation in genetics. To the best of our knowledge, the entire offering in the firench language from 1900 to 1936 of didactic books, textbooks, and books for the layman specifically devoted to genetics is limited to those listed in Table 1.

Table One

French T'extbooks Devoted to Genetics, 1900-1936

1923: T. Morgan, A. Sturtevant, H. Muller, and C. Bridges, Le mécanisme de

l'hérédité mendélienne, trans. M. Herland (Brussels: Lamertin).

1924: E. Guyénot, L'Hérédité (Paris: Doin; 2nd ed., 1930; 3rd ed., 1942; 4th ed., 1948).

1928: 1. Blaringhem, Principes et formules de l'hérédité mendélienne (Paris:

Gauthiers-Villars).

J. Rostand, Les chromosomes, artisans de l'hérédité et du sexe (Paris:

Hachette).

1930: J. Rostand, De la mouche à l'homme (Paris: Fasquelle).

1934: Ph. LHéritier, Génétique et évolution. Analyse de quelques études

mathématiques sur la sélection naturelle (Paris: Hermann).

1935: M. Caullery, Les conceptions modernes de l'hérédité (Paris: Flammarion).

1936: L. Cuénot and I. Rostand, Introduction à la génétique (Paris: Centre de documentation universitaire).

T. H. Morgan, Embryologie et génétique trans, J. Rostand (Paris: Hermann).

A close examination of Table 1 reveals that the output is, in a way, even skimpier than one might at first realize. Consider the items on the list more closely: The first text is a Belgian translation of an American classic, and was not published until well after World War I. Guyenot's textbook, probably one of the best textbooks of Mendelian genetics ever written, dominated the French-language market for nearly forty years - but Guyénot himself taught in quasi-exile in Geneva, and none of his students in genetics became established in France. Blaringhem was one of the most famous Lamarckians and polemical anti-Mendelians of his time; though his book represented Mendelism reasonably accurately, it placed the importance of Mendelian theory in doubt. Jean Rostand never worked in a university or in any other institution of higher learning or research institute. Furthermore, one of the items on our list, the 1934 volume by LHéritier, is a forty-three-page booklet dealing with the abstract models of population genetics. As such, it served to stimulate research in population genetics, but had little effect on the broad acceptance of Mendelism. (The place of L'Héritier's work will be discussed further below.) 
A brief comparison with similar books in English and in German reinforces the point that there was a great deal more publication of this sort in America, England, and Germany than there was in France. An incomplete and sketchy list of the items published to 1923, already longer than the French list to 1940, is provided in Table 2.

Table Two

A Partial List of Textbooks on Genetics, 1900-1923

A. In English

1902: W. Bateson, A Defence of Mendel's Principles of Heredity (Cambridge: Cambridge University Press).

1905: R. C. Punnett, Mendelism (Cambridge: Cambridge University Press; 2nd ed., 1907; 3rd ed [New York: Macmillan], 1911; 4th ed., 1912; 5th ed., 1919; 6th ed., 1922; trans. into German, 1910).

1906: R. H. Lock, Recent progress in the Study of Variation, Heredity, and Evolution (London and New York: Dutton; 2nd ed., 1911).

1909: W. Bateson, Mendel's Principles of Heredity (Cambridge: Cambridge

University press; 3rd imp. with additions, 1913 ; trans. into German as Mendels Vererbungstheorie [Leipzig: Teubner], 1914.

1911: A. D. Darbishire, Breeding and the Mendelian Discovery (London: Cassell). 1912: W. E. Castle, J. M. Coulter, C. P. Davenport, E. M. Fast, and W. I . Tower, Heredity and Eugenics (Chicago: University of Chicago Press).

1913: W. Bateson, Problems of Genetics (New Haven: Yale University Press).

H. E. Walter, Genetics, An Introduction to the Study of Heredity (New York: Macmillan; 2nd ed., 1922).

1915: T. H. Morgan, A. H. Sturtevant, H. J. Muller, and C. B. Bridges, The Mechanism of Mendelian Heredity (New York: Holt; rev. ed., 1922).

R. Pearl, Modes of Research in Genetics (New York: Macmillan).

1916: W. E. Castle, Genetics and Eugenics (Cambridge, Mass: Harvard University Press; 2nd ed., 1920).

1918: W. B. Brown and R. E. Clausen, Genetics in Relation to Agriculture (New York: McGraw-Hill).

1919: T. H. Morgan, The Physical Basis of Heredity (Philadelphia: Lippincott).

B. In German

1909: W. Johannsen, Elemente der exakten Erblichkeitslehre (Jena: Gustav

Fischer; 2nd ed., 1913).

1911: E. Baur, Einführung in die experimentelle Vererbungslehre (Berlin:

Borntraeger; 2nd ed., 1914; 6th ed., 1919.

R. B. Goldschmidt, Einfïhrung in die Vererbungswissenschaft (Leipzig:

Engelmann; 2nd ed., 1913; 3rd ed., 1920; 4th ed., 1923.

V. Haecker, Allgemeine Vererbungslehre (Braunschweig: Vieweg: 3rd ed., 1921).

1913: L. Plate, Vererbungslehre (Leipzig: Wilhelm Engelmann).

This comparison makes it extremely clear why research in Mendelian genetics was nearly totally absent in France between 
World War I and the mid-thirties. A whole generation was simply deprived of the training and information that they would have needed to carry out such research. They were taught that Mendelism had little to offer to such fundamental disciplines as embryology, microbiology, and physiology and that, although correct as far as it went, it did not deal with the fundamental characters of organisms (see below, section 1.4). Accordingly, Mendelian genetics was treated as a foreign paradigm of marginal importance, not worth close attention in the curriculum. Not surprisingly, given these circumstances, during this period most French biologists who concerned themselves with Mendelism treated it as a topic of debate on which they could pass judgment without themselves conducting original genetic research. In most instances, the judgment that was rendered fell between two extremes: a rancorously negative rejection of Mendelism, or an acceptance of its limited truth together with a denial of its fundamental importance or its value as a guide to serious research into heredity.

There is another aspect of this situation that deserves exploration. Beyond mere chauvinism and occasional incomprehension, there were also institutional obstacles to the introduction of Mendelism arising from the structure of the French university system. These include the complete separation of disciplines, the virtual impossibility of recruiting foreign scholars, ${ }^{2,3}$ the legally defined primary imperative of the entire system - namely, the production of an elite corps of high school teachers on the basis of national programs and competitions - and the intellectual conservatism of the central authorities in curricular matters. The importance of such factors in placing significant obstacles in the path of the new and controversial science of genetics requires further analysis.

\subsection{Mendelian Research before 1940}

It is commonly held that Mendelian research in France was a desert, with some sporadic but heroic exceptions - foremost among them, Cuénot. This is an ahistorical vision of the problem. In fact, French biologists did considerable Mendelian research (as well as research on Mendelism of the sort just described) before

23. Although we have not undertaken a systematic survey, to the best of our knowledge there were only two non-French citizens called to chairs in the entire history of the French universities until the 1950s - namely Erasmus and Jean Piaget. 
World War I; then came a virtually total celipse lasting nearly twenty years; and finally, the mid-thirties mark a renaissance of Mendelian research. Accordingly, we shall organize our account around two questions: (1) How and why did the French biologists abandon genetics around World War I? (This question is very different from the usual one: why didn't they practice genetics at all?) (2) Under what conditions did the renaissance of the midthirties occur?

Let us begin with the enigmatic case of Cuénot (1866-1951). On an international scale, he was one of the most productive geneticists during the first decade after the rediscovery of Mendel. Yet he himself eventually turned away from research in genetics, and he actively discouraged students from entering the field. On this occasion we can only summarize his contributions to Mendelian genetics and put forward a brief statement of the puzzle presented by his virtual abandonment of genetic research.

Cuénot's elegant contributions to Mendelian genetics are largely contained in the papers listed above in note 6 . For our purposes, they may be conveniently summarized under five headings:

(1) Extension of Mendel's first two laws to the animal kingdom. In 1902, roughly in parallel with Bateson's work on guinea pigs, ${ }^{24}$ Cuénot demonstrated that Mendel's law of the disjunction of characters applies not only to plants, but also to animals - specifically, mice. ${ }^{25}$ Shortly afterward, he provided examples of the application of Mendel's second law to mice. As will be rapidly apparent, the extension of this work yielded a fundamental deepening of the Mendelian account of inheritance.

(2) Identification of what would now be called multiple alleles. Cuénot established on the basis of firm experimental evidence that there are multiple forms of the same determinant [i.e., gene]. For example, he identified four alternative forms of a single determinant affecting pigmentation. ${ }^{26}$

(3) Recognition of interaction among different determinants. Cuénot used the term "descriptive character" for characters such as coat color which, although they appear simple, are genetically complex. A unit character, in contrast, was one

24. See, e.g., W. Bateson and E. R. Saunders, "Experimental Studies in the Physiology of Heredity," Rep. Evol. Comm. Roy. Soc., l (1902), 1-160.

25. L. Cuénot, "La loi de Mendel" (above, n. 6), and an article of the same title with virtually the same text in Comp. Rend. Acad. Sci., 134 (1902), 779781.

26. Cuénot, 3ème, 5ème, and 7ème notes. 
controlled by a single determinant. ${ }^{27}$ (This usage was easily switched when Johannsen's "gene," "genotype" and "phenotype" became available.) This point also yielded:

(4) Recognition that one particular form of the interaction among determinants can be to mask the normal effect of a particular determinant. ${ }^{28}$ For example, the recessive determinant for albinism, in double dose, could mask the development of coat color, for which all the remaining determinants were present. ${ }^{29}$ This was perhaps the first, and certainly one of the most important, of the early analyses of what came to be called "epistasis." The demonstration that albino mice transmit factors that determine the coat color of their offspring led Cuénot to emphasize that even such a "simple" trait as coat color is the result of the interaction of many determinants controlling formation (or not) of pigment, pigment type, patterns of deposition, etc. ${ }^{30}$

(5) Recognition that certain combinations of characters cannot yield viable offspring. In crosses between yellow mice, Cuénot noticed that homozygotes for yellow coat color never appeared. This observation, coupled with a slight distortion of the usual Mendelian ratios in his sample, led him to propose that sperm carrying the yellow determinant were incapable of fertilizing eggs carrying that same determinant. It was only after Castle and C. C. Little obtained clear 2:1 ratios of yellow to nonyellow in a large sample that they proposed ${ }^{31}$ (what Cuénot accepted shortly afterward ${ }^{32}$ ) that what was involved was not differential fertilization, but a failure of the fertilized egg to complete embryonic development. Some years later, the lethal condition was verified by the discovery of dead embryos in utero

27. Cuénot, "5ème note," p. 10.

28. Although implicit as early as the "2ème note," this is explicitly stated in the "5ème note," p. 3.

29. Ibid.

30. Ibid., p. 10.

31. W. Castle and C. C. Little, "On a Modified Mendelian Ratio among Yellow Mice," Science, 32 (1910), 868-870. Castle and Little were building, in turn, on Baur's analysis of lethal genes in Antirhinum; cf. Erwin Baur, "Untersuchungen über die Erblichkeitstverhältnisse einer nur in Bastardform lebensfähige Sippe von Antirrhinum majus," Ber. deut. botan. Gesell., 25 (1907), $442-454$.

32. Cuénot, "7ème note," p. 47: "il paraît bien que les gamètes porteurs du déterminant $\mathrm{J}$ [Jaune, for yellow] forment, lors qu'ils sont unis, un zygote JJ qui n'est pas viable et meurt sans se développer; il n'y a que les zygotes renfermant J dominant un autre déterminant allélomorphe ( $\mathrm{G}, \mathrm{G}$ ou $\mathrm{N})$ qui peuvent évoluer." 
in yellow females. ${ }^{33}$ Cuénot himself had already interpreted other ratios as the result of reduced viability rather than as the consequence of flaws in the Mendelian system of segregation. $^{34}$

Cuénot's series of papers on coat color inheritance makes it clear that he placed ever greater reliance on Mendelism as a means of explaining hereditary phenomena. At first he appears to have believed that Mendelian inheritance represented just one of many modes of inheritance. He came to endorse it as the major mode of inheritance, however, as he learned how to explain more and more of what appeared, on the surface, to be non-Mendelian patterns (aberrant ratios, etc.) by the interplay of multiple, independently identifiable determinants. By the end of the series of papers on coat color, in interaction with such other experimentalists as Bateson, Castle, Darbishire, M. Durham, and L. H. Plate, he had identified six independent determinants, each of which was involved in the production of coat color even in the "simple" case of a uniform gray or black coat.

At the heart of Cuénot's account of the phenomena he encountered here was a hypothetical mechanism for the production of pigment. Citing Biedermann ${ }^{35}$ and others, who suggested that the action of tyrosinase on a chromogen produced pigmented substances in plants, Cućnot cxtended this vicw to suggest that "a single chromogen with two diastases" [here meaning enzymes] one for black and one for yellow - could account for a major portion of the experimental results. ${ }^{36}$ One determinant, with forms $\mathrm{C}$ (presence of chromogen) and A (absence thereof), would be responsible for there being pigment formation or no pigment formation; two others (for black and yellow), each with various variants, would account for various features of the pigments that were actually produced. His interpretation of coat color was thus intimately related to a physiological scheme for the production of pigment and was readily expanded to take account of interactions between determinants or their products. In employing this scheme,

33. Cuénot reported these results many years later in "Génétique des Souris," Bibl. Genet., 4 (1928), 179-242, ascribing them to H. Ibsen and E. Steigleder, "Evidence for the Death in Utero of the Homozygous Yellow Mouse," Amer. Nat., 51 (1917), 740-752, and to W. Kirkham, "The Fate of Homozygous Yellow Mice," J. Genet., 28 (1919), 125-135.

34. See, for example, his treatment of Japanese waltzing mice in "6ème note," pp. $12-14$.

35. "2ème note," p. 38. Cuénot does not supply the full reference.

36. Ibid. 
Cuénot was among the very first to propose that gene function is related to the production of enzymes and that each gene could be associated with the production of an identifiable product. We will return to this point toward the end of this article. In many respects, this line of work marks the beginning of what later became physiological genetics. Richard Goldschmidt, J. B. S. Haldane, and Sewall Wright all explicitly acknowledged their debt to him.

Indeed, returning to a broad range of physiological issues concerning the defense mechanisms of cells against foreign substances and parasitic agents, ${ }^{37}$ Cuénot turned in 1908 to the physiology and genetics of cancer in mice. ${ }^{38}$ Combining Mendelian analysis with a study of the ability of mice to tolerate grafts, he established that tissues having the same genotype behave differently according to the genotype of surrounding tissues. In other words, he provided an experimental formulation of the question of the way in which certain genes, in order to achieve their characteristic effects, depend on the presence of something supplied by contact with other cells. Under the label of "non-autonomy," this question was pursued twenty years later by A. H. Sturtevant working with Drosophila mosaics and thirty years later by Boris Ephrussi and George Beadle in their transplantation experiments on Drosophila.

In short, Cuénot's accomplishment was not only to found French genetics, but also to provide it with a distinctivcly physiological perspective. And yet there is no direct line between his

37. For a detailed account of Cuénot's earlier interests of considerable relevance to our discussion, see Camille Limoges, "Natural Selection, Phagocytosis, and Preadaptation: Lucien Cuénot, 1886-1901," J. Hist. Med. Allied Sci., 31 (1976), 176-214.

38. So far as we know, with the exception of a single paper (C. Jensen, "Experimentelle Untersuchungen über Krebs bei Mäusen," Centralbl. Bakter. Parasit., 1. Abt., 34 [1903], 28-34, 122-143), Cuénot and his collaborators were the only group to work on this topic at the time. Their most remarkable result was probably the observation of a reversal of dominance resulting from a graft. Cuénot began his long series of publications with L. Mercier on the inheritance of cancer in mice in 1908. See, e.g., L. Cuénot and L. Mercier, "Études sur le cancer des Souris. Y-a-t-il un rapport entre les différents mutations connues chez les Souris et la réceptivité à la greffe?" Comp. Rend. Acad. Sci., 147 (1908), 1003-1005; "Études sur le cancer des Souris. Sur l'histophysiologie de certaines cellules du stroma conjonctif de la tumeur B," ibid., 147 (1908), 1340-42; "Études sur le cancer des Souris. Relations entre la greffe de tumeur, la gestation, et la lactation," ibid., 149 (1909), 1012-13; and "Études sur le cancer des Suuris. L'hérédilé de la sensibilité à la greffe cancereuse," ibid., 150 (1910), 1443-46. See also "L'hérédité de la sensibilité à la greffe cancereuse chez les Souris. Résultats confirmatifs," Comp. Rend. Soc. Biol., 69 (1910), $645-646$. 
work and that of his successors three to five decades later. In spite of his undeniable institutional power and his continued importance in general biology, he founded no school or tradition of genetics or physiological genetics, and none of his pupils went into genetics.

Why not? Why did he not become France's Bateson? What we know is that when he turned to work on the inheritance of cancer, Cuénot drifted away from studies of the Mendelian transmission of characters, returning to the physiological and evolutionary topics in which he had been interested earlier. During the 19141918 war, when Nancy was occupied, his stocks of mice were destroyed. He never reconstituted them, devoting most of his energy to the themes of species and evolution. And from the earliest days on, he sought to dissuade his students from writing doctoral theses on genetics, warning them that such a thesis would prevent them from finding a position in the French universities. ${ }^{34}$

There were, of course, other French scientists who took an interest in Mendel's laws and in mutation theory before World War I. But their work was largely routine; its aim was simply to verify or falsify Mendel's laws in application to yet one more organism. This strategy of verification was employed by the botanists as early as 1900 . Some, like P. Vilmorin, confirmed Mendel's laws; ${ }^{40}$ others put them in competition with the hypotheses of Charles Naudin. The empirical work was sometimes considerable (e.g., the work of Blaringhem), ${ }^{41}$ but the result was usually to restrict the application of Mendel's laws to particular cases. By and large, such work reveals a failure to comprehend Mendel's methodology. The objections to Mendelism put forward in this literature are typical of those raised by field naturalists internationally.

The strategy of verifying Mendel's laws is seen in a much more ambitious project in the Pasteurian tradition, begun in 1909. Two students of Caullery, Delcourt and Guyénot, undertook a study on the determination of mutations in Drosophila. ${ }^{42}$ The experimental

39. A. Tetry in the discussion of P. L'Héritier, "Souvenirs" (above, n. 21), p. 347.

40. E.g., P. Vilmorin, "Recherches sur l'hérédité mendélienne," Comp. Rend. Acad. Sci., 151 (1910), 548-551.

41. L. Blaringhem, "Sur les hybrides d'Orges et la loi de Mendel," Comp. Rend. Acad. Sci., 148 (1909), 854-857, and "Les règles de Naudin et les lois de Mendel relative à la disjonction des caractères hybrides," ibid., 152 (1911), 100-102. Sec also the discussion of Blaringhem in Buican, Histoire de la génétique (above, n. 1), pp. 247-261.

42. See above, n. 17. See also A. Delcourt, "Sur l'apparition brusque et I'hérédité d'une variation chez Drosophila confusa," Comp. Rend. Soc. Biol, 66 
objective was to control the nutrition of the flies and to raise them in an aseptic environment; the theoretical hope was to show that the new conceptions of the geneticists were biased by failure to exercise proper control over the experimental conditions. (It is worth recalling that this is the line of work that was strongly supported by the anti-Mendelian Rabaud.) Guyénot indeed succeeded in controlling the flies' nutrition and the sterility of the medium. By 1917, when he presented his doctoral thesis, he had counted 400;000 flies, but he had observed the opposite of what he had been looking for: the mutants did not change in an altered environment, and spontaneous mutations appeared in a constant environment. ${ }^{43}$ Furthermore, he had been able to verify the exactness of Mendel's laws on stable mutants given him in 1913 by T. H. Morgan. ${ }^{44}$ So the thesis turned into a huge affair of methodology, with negative results: neither food type nor the presence of microorganisms had any effect on the process of mutaton.

The attitude informing this project is characteristic of the

(1909), 709-711; A. Delcourt and E. Guyénot, "De la possibilité d'étudier certains diptères en milieu défini," Comp. Rend. Acad. Sci., 15l (1910), 255257; A. Delcourt and E. Guyénot, "Variation et milieu: lignées de Drosophiles en milieu stérile et défini," Comptes rendus de la IVème Conférence internationale de Génétique (Paris: Masson, 1911), pp. 478-486; E. Guyénot, "Études biologiques sur un mouche, Drosophila ampelophila Löw," Comp. Rend. Soc. Biol., 74 (1913), 97-99, 178-180, 223-225, 270-272, 332-334, 389-391, 443445; E. Guyénot, "Études biologiques sur la mouche, Drosophila ampelophila Löw. Nécessité de réaliser un milieu défini," ibid., 71 (1914), 483-485; "Premiers essais de détermination d'un milieu nutritif artificiel pour l'élevage d'une mouche, Drosophila ampelophila Löw," ibid., 548-550.

43. E. Guyénot, "Recherches expérimentales sur la vie aseptique et le développement d'un organisme en fonction du milieu," Bull. Biol. Fr. Belg., 51 (1917), 1-330.

44. E. Guyénot. "Loeuvre de T. H. Morgan et le mécanisme de l'hérédité," Rev. Gén. Sci. Pures Appl., 29 (1918), 264: "J'ai pu, grâce à l'obligeance de T. H. Morgan, avoir entre les mains un certain nombre des mutations sur lesquelles ont porté ses recherches. Après avoir rendu aseptiques les élevages de ces lignées, j'ai pu refaire la plupart des croisements déjà réalisés par les auteurs américains et me convaincre, par moi-même, et d'après des pourcentages considérables, de la légitimité des résultats annoncés," In a footnote, Guyénot adds: "Ces recherches, qui datent de 1913-1914, n'ont pas encore pu être publiées." The date of 1913 for the receipt of Morgan's flies is explicitly confirmed in a later publication ( $E$. Guyénot, "Recherches sur un cas d'hérédité 'sex-linked'; la Drosophile à oeil "barred", Mém. Soc. Phys. Hist. Nat. Genève, 39, fasc. 5 [1920|), an article which begins with these words: "Les recherches qui font l'objet de ce mémoire ont ete effectuées sur des Drosophila ampelophila, mutation 'barred eyes' que Th. $H$. Morgan eut lobligeance de madresser en 1913." It should be recalled that "Drosophila ampelophila Löw" is a synonym for "Drosophila melanogaster." 
climate in which genetics was received. Guyénot began work as a Lamarckian - but the essential commitments of his project did not stem from his Lamarckism, for that did not suffice to determine his methods. The key to understanding his experiments is the recognition that they belong within the theoretical frameworks of assimilation and infection. In effect, Guyénot brought genetics before a tribunal composed of Claude Bernard and Louis Pasteur. But in this case genetics won; Guyénot was converted to Mendelism. Having turned on his teachers and declared his allegiance to the genetics of the Morgan school, Guyénot (with the support of Caullery) became embroiled in a prolonged and vicious polemical debate with Rabaud and Raymond Hovasse. ${ }^{45}$ It was perhaps on these grounds (though we have no firm evidence on the point) that he was unable to find a proper position in France; after the war, he settled into exile in Switzerland.

Given this history, the effects of which were greatly aggravated by the ravages of World War I on the generation that reached adulthood in the twenties, it is easy to understand the complete absence of genetics in France for nearly twenty years. None of Cuénot's intellectual descendants were geneticists. Guyénot had left the country. The strategy of verification did not produce anything interesting. Effectively speaking, Mendelian genetics was not taught in the universities; furthermore, it was associated with violent verbal polemics that brought it into poor repute.

In these circumstances, it is worth inquiring how Mendelism returned to France. To treat this question fully, we would have to reach beyond the confines of conceptual and methodological approaches to the subject. It would be necessary to examine the institutional settings in which, on the one hand, the resistance to genetics was embedded and within which, on the other, genetics found its new foothold. We cannot enter fully into the relevant institutional history here; instead, we confine ourselves to a few remarks (to be followed up in a subsequent paper) that indicate the directions in which to turn. Most genetic research between the

45. This controversy began with Guyénot, "L'oeuvre de T. H. Morgan," and continued for two decades, most prominently in the Bulletin biologique de la France et de la Belgique. As late as 1937, in an issue containing two of Ephrussi and Beadle's articles on their transplantation experiments, one finds three articles with self-explanatory titles: $M$. Caullery, "À propos des commentaires sur l'hérédité de M. Rabaud" (pp. 1-9); E. Guyénot, "La génétique et les illusions de M. Rabaud" (pp. 10-21); and E. Rabaud, "À propos de hérédité: Réplique à deux réponses." The articles are not merely polemical, they strive for insult. This is made the more remarkable by the fact that all three authors were on the editorial board of the journal. 
two wars was performed outside the universities in the Institut du Radium, the Institut National de la Recherche Agronomique, the École Vétérinaire d'Alfort, the Collège de France, the Institut Pasteur, the Institut de Biologie physico-chimique, and the École Normale Supérieure. ${ }^{+6}$ For the most part, those places produced only sporadic and routine work, of little theoretical interest. But three of them sheltered research that proved to be of great importance for the general history of genetics - the Ecole Normale Supérieure (which is of particular importance for the rebirth of Mendelism in France), the Institut Pasteur, and the Institut de Biologie physico-chimique.

The importance of the École Normale rests on the work of Teissier and L'Héritier, the founders of a strong tradition of Mendelian population genetics. Both of them were originally mathematicians, and they both wanted to introduce formal methods into biology. In 1931, at the instigation of the physiologist André Mayer, L'Héritier was awarded a Rockefeller fellowship to learn genetics in the United States. ${ }^{47}$ When he returned to France, he joined Teissier with the objective of testing the models of theoretical population genetics in defined experimental conditions. They invented the population cage, a tool for the study of the "experimental evolution" of thousands of flies over an indefinite number of generations. ${ }^{48}$ Their studies of the evolution of mixed populations of Drosophila rapidly produced a major theoretical problem: by 1937 it was apparent that genes known to be unfavorable were maintained indefinitely at equilibrium in an experimental population. ${ }^{14}$ This was the first direct support for the existence of a balanced polymorphism at the level of the gene.

For our purposes, it is worth noting an important accidental discovery made in the course of this work, less for its intrinsic interest (which is very great) than for what it reveals about the

46. Formally, as Harry Paul has reminded us, the École Normale was incorporated into the University of Paris in 1903. In practice, however, it retained considerable autonomy; its curriculum was not well integrated into the university's.

47. Ph. L'Héritier, "Souvenirs," p. 335.

48. Ph. L'Héritier and G. Teissier, "Étude d'une population de Drosophiles en équilibre," Comp. Rend. Acad. Sci., 197 (1933). 1765-67; "Une expérience de sélection naturelle. Courbe d'élimination du gène "bar' dans une population de Drosophiles en équilibre," Comp. Rend. Soc. Biol., 117 (1934), 1049-51; and "Recherches sur la concurrence vitale. Études de populations mixtes de Drosophila melanogaster et Drosophila funebris," ibid.. 118 (1935), 1396-98.

49. Ph. L'Héritier and $\mathrm{G}$. Teissier, "L'élimination des formes mutantes dans les populations de Drosophiles. I. Cas des drosophiles bar". II. Cas des Drosophiles "ebony,", Comp. Rend. Soc. Biol., 124 (1937), 882-884. 
climate of the time and the pattern of investigation that characterized the return of Mendelism. In order to count the thousands of flies grown in the population cages, L'Héritier and Teissier used carbon dioxide as an anaesthetic, photographed the flies, and then did their counts on the photographic plates. It turned out that certain strains of flies were sensitive to the carbon dioxide and were killed by light doses. In investigating this sensitivity, L'Héritier and Teissier established that it was not transmitted in a Mendelian pattern - indeed, that it was cytoplasmically (and hence largely maternally) inherited. ${ }^{5(1)}$ In an interview, ${ }^{51}$ L'Héritier reported that he and his (largely American) geneticist colleagues were quite astonished at this result, but that most of the French biologists with whom he discussed it were not in the least surprised. What struck them as odd was that he found such a mode of transmission to be surprising. ${ }^{5 ?}$

Although this reintroduction of Mendelian genetics into France is, in certain respects, a tale of institutional marginality, that situation was dramatically altered by accidents of circumstance connected with World War II. During the war, Teissier was one of the leaders of the French Resistance. Afterward, he became director of the Centre National de la Recherche Scientifique (CNRS), which, in France, serves (among others) a combination of the missions served by the National Science Foundation and the National Institutes of Health in the United States. Teissier received the support of an extremely influential group of physicists and chemists, many of them leaders in the Resistance, including

50. Philippe L'Héritier and Georges Teissier, "Une anomalie physiologique héréditaire chez la Drosophile," Comp. Rend. Acad. Sci., 205 (1937), 1099_1101; P. L'I Iéritier and G. Teissier, "Une mécanisme héréditaire aberrant chez la Drosophile," ibid., 206 (1938), 1193-95; P. L.'Héritier and G. Teissier, "Transmission héréditaire de la sensibilité au gaz carbonique chez la Drosophile," ibid., $206(1938), 1683-85$.

51. Held at Ambert, France, November 1984.

52. Although we cannot expand on the point in the present paper, L'Héritier's pursuit of $\mathrm{CO}_{2}$ sensitivity during and after the war illustrates the themes of this paper quite nicely. His analysis led him to ascribe the inheritance of sensitivity to the workings of a "génoïde," a cytoplasmically inherited gene or genetic complex. Further analysis of the physiology and physical properties of the génoïde eventually led to the recognition that the inherited agent was a virus. One side effect of this work was that L'Héritier was the founding director of the Laboratory of the Genetics of Viruses at the CNRS (see the next paragraph of the text regarding the CNRS). Early references are collected in Ph. L'Héritier, "Génoïdc scnsibilisant la Drosophilc à l'anhydride carbonique," in Unités biologiques douées de continuité génétique (Paris: CNRS, 1949), pp. 113-122. References to subsequent articles may be found in Buican, Histoire de la génétique, pp. $342 \mathrm{ff}$. 
Frédéric Joliot-Curie and Pierre Auger. It was these allies whose support allowed Teissier to organize the penetration of genetics into the central institutions of France, against the opposition of the university biologists.

The two other places with which we will be concerned, the Institut Pasteur and the Institut de Biologie physico-chimique, made their primary contribution to the history of genetics outside the classical Mendelian framework. We will treat them separately below.

\subsection{The Polemics}

Before leaving this history of the reception of Mendelism in France, we must say something about the polemical debates surrounding Mendelism. These polemics occupied much of the intellectual energies of French biologists interested in heredity. Four arguments recurred constantly, both in popular texts and in the more refined analyses. The arguments are:

1. Mendelian characters are "ornamental." 53 They concern "special heredity," and not "general heredity."

2. Mendelian genetics is a formal description. It does not say anything about the physiology of heredity.

3. Mendelian genetics neglects the cytoplasm. (This argument was typically put forward by embryologists.)

4. Mendelian genes are in reality symbiotic microbes, "diathèses." 54 (This relatively unconventional argument was

53. An important popularizer of this image was F. Le Dantec, who had been a pupil of Pasteur; see, e.g., F. Le Dantec, La crise du transformisme (Paris: Flammarion, 1909), chap. 1.

54. This is an old medical word (diathèse" in French) that originally meant predisposition to disease. It was typically used for unknown or unspecific endogenous sources of disease or infection. Le Dantec first presented this argument in "L'hérédité des diathèses ou hérédité mendélienne," Rev. Sci., 5th ser. 1 (1904), 513-517, and in sect. 56 of Les influences ancestrales (Paris: Flammarion, 1904), pp. 267-283. These texts, incidentally, show a thorough comprehension of Cuénot's early papers on inheritance in mice. This is typical of the serious biological texts of the day. In 1909, in La crise du transformisme, Le Dantec returns to this objection in a historically interesting formulation: "ILes expériences d'hérédité mendélienne prouvent que], à côté du patrimoine héréditaire capable de reproduire les mécanismes vivants, il peut y avoir dans l'oeuf des microbes surajoutés qui déterminent, chez l'être provenant de l'oeuf, des caractères surajoutés. En raisonnant ainsi. je me borne à substituer le langage de Pasteur au language de Weismant. ... Les caractères mendéliens sont des maladies chimiques ou diathèses, et voila tout" (Leçon 7). 
advanced in the most virulent pamphlcts, cspccially those of F. Le Dantec.)

According to the first argument, Mendelian genetics says nothing about the inheritance of the most general characters of life - that is, such essential functions as respiration and Bauplan. In that respect, Mendelism is of no interest for "general biology." This criticism is not always as exaggerated as some of the quotations suggest. When Ephrussi reported in 1947 that he had discovered a "mutant" in yeast that did not respire, many geneticists (including such figures as Charlotte Auerbach) ${ }^{5.5}$ were incredulous, but his announcement provided great satisfaction for many of the old anti-Mendelians. Here, at last, was a mutation that affected a fundamental function and, as Ephrussi showed, it was not inherited in a Mendelian manner!

Turning to the second argument, we note that Rabaud, who was probably the strongest critic of Mendelism before 1940, opposed his personal "physiological theory of inheritance" to the "theory of factors." 56 This theory, though widely discussed, was purely verbal. But, as will become clearer below, there is an intriguing parallel between Rabaud's purely ideological criticisms and the effective work of such French geneticists as Cuénot, Ephrussi, François Jacob, and Jacques Monod, all of whom worked primarily on "physiological genetics." Their work, in a way, served as the answer to this group of criticisms.

In discussing the third argument, it is worth recalling that during the first half of this century embryology was one of the premier disciplines among French-speaking university biologists. Among the figures of note, one should include the Belgian A. Brachet, Dastre, Dalcq, Emmanuel Fauré-Fremiet, Rabaud, Teissier, Paul Wintrebert, and many others. The argument is the synthesis of the two preceding ones: the cytoplasm is the place where the general functions of life are carried out and where differentiation occurs; ${ }^{57}$

55. Interview with P. P. Slonimski, Gif-sur-Yvette, November 1984.

56. In 1909, Rabaud undertook to demonstrate the validity of Cuénot's work on mice. One result was a large and confusing memoir of 313 pages on "The Physiological Theory of Heredity," published as Supplement I of Bull. Biol. Fr. Belg. in 1919 under the title of "Recherches sur l'hérédité et la variation: Étude expérimentale et théorie physiologique." See ajso, for instance, F. Rabaud, "Sur une anomalie héréditaire des membres postérieurs de la souris," Comp. Rend. Soc. Biol., 77 (1914), 411-412; "Sur une variation héréditaire spéciale au sexe mâle: Les souris grises blanchissant," ibid., 78 (1915), 58-59 and "Les grandes lignes d'une théorie physiologique de l"hérédité," ibid., 79 (1917), 738-744.

57. See, for example, Rabaud's criticisms of Morgan's theory in his chapter on "L'hérédité," pp. 268-303 of Éléments de biologie générale (Paris: Félix 
since all the cells of a higher organism contain the same complement of genes, and since these are restricted to the nucleus, what must be explained is how these general functions are inherited and how differentiation is controlled. In particular, according to the standard embryological account, an additional system of inheritance, located in the cytoplasm, must control differentiation and hence the general structure of higher organisms. This was considered by many to be the primary system of inheritance, a fact that helps to explain the reaction of embryologically oriented biologists to the work on carbon dioxide sensitivity. Here again, French geneticists, when they come onto the scene, find a complex of problems of central importance, one that they cannot ignore. Ephrussi's work on the development of pigmentation in Drosophila, on respiration in yeast, and on cellular hybridization, for example, cannot be understood properly except in light of these issues. ${ }^{5.8}$

The fourth argument appealed to the tradition of Pasteur against the "metaphysics of hereditary determinants," and preformist metaphysics. Le Dantec, who was a student of Alfred Giard (an important neo-Lamarckian) as well as Pasteur, did no experimental work and did not make a significant contribution to biology, but he had a huge audience as a popular writer. His argument was obviously a projection of the popular prestige of microbiology. The irony of Le Dantec's invocation of the Pasteurian perspective is inescapable: it was mainly in the Pasteur Institute that the French school of molecular genetics emerged -

\footnotetext{
Alcan, 1928). Here are two characteristic passages. Against the view that the nucleus is the sole bearer of heredity: "Or, cette hypothèse fondamentale soulève contre elle tous les faits précédemment mis en lumière, qui montrent que noyau et cytosarque forment un complexe indivisible. Refuser au cytosarque toute valeur dans les processus de continuité héréditaire, tenir cette négation pour un fait acquis et bâtir sur elle un système entier, nous met complètement en dehors du domaine de la spéculation scientifique. Plusieurs biologistes, du reste, concèdent au cytosarque une certaine importance dans la détermination des particularités très générales, telles que l'existence, la position et la proportion relative des organes futurs; les caractères spécifiques et individuels appartiendraient au noyau. Le fait d'avoir deux yeux dépendrait du cytosarque; la forme de ces yeux, le contenu de liris dépendraient du chromosome. Cette conception revient à considérer cytosarque et noyau comme un complexe indivisible et à voir dans la continuité héréditaire la continuité du complexe" (p. 285). "Tout d'abord, du point de vue héréditaire, la distinction entre le noyau et le cytosarque n'est pas plus défendable que du point de vue strictement physiologique. L'équivalence fonctionnelle des duex parties ne fait aucun doute et rien ne nous autorise à admettre la moindre restriction" (p. 289).

58. Both P. P. Slonimski and $M$. Weiss made this point in independent interviews, Gif-sur-Yvette, November 1984, and Paris, October 1985.
} 
and, at that, working in part with hereditary infection: infection by prophage of lysogenic bacteria. The antecedents of this story belong at the center of the second part of this paper.

There is no denying the reality and the vitrio":c character of the anti-Mendelian polemics. But the excesses of the polemicists should not mask the fact that there were real biological issues raised in each of these arguments - issues that the Mendelians had serious difficulty in resolving. Nor should they mask the fact that each of these arguments was connected with first-class research programs that contributed to the formation of molecular biology, indeed, molecular genetics, in France.

\section{EXTRA-MENDELIAN PREHISTORY OF THE FRENCH SCHOOL OF MOLECULAR GENETICS: 1900-1945}

We now come to the question formulated at the beginning of this study: If there was no real tradition of Mendelian research in French biology before World War II, what was the rootstock out of which the French school of molecular genetics, clearly flourishing by the late forties or early fifties, emerged?

Two institutions played a key role between the two wars: the Institut Pasteur, and the Institut de Biologie physico-chimique. Each place harbored a distinctive approach to hereditary phenomena. We have in mind, first, the work of those microbiologists at the Pasteur who came to think of some phenomena in unicellular organisms and bacteriophage in terms of heredity - particularly the work of Eugène Wollman and André Lwoff - and second, the work of Ephrussi on the physiology of gene action in the pigmentation of the Drosophila eye.

Both approaches went against the grain of classical Mendelian methodology, yet they proved decisive in the formation of molecular genetics. In order to make clear how distinctively non-Mendelian these research traditions were, we will employ an extremely generous definition of Mendelian methodology: we will count any research on hereditary phenomena as employing classical Mendelian methodology provided that it requires, as part of the experimental protocol, the making of sexual crosses and the analysis of the products of those crosses. Even by this generous definition, much of the research at the Pasteur and, perhaps more surprisingly, much of Boris Ephrussi's research does not count as Mendelian. The Pasteurians did not make crosses because conjugation was unknown or uncontrollable in their organisms, and Ephrussi, although he was working on mutants isolated by Morgan and his colleagues, did not require crosses in his experimental 
protocols because he was interested in something else, which he called physiological genetics.

\subsection{From Contagion to Heredity}

Let us begin with the Pasteurians. Microbiology, particularly Pasteurian microbiology, has long been, and may still be, the main glory of French biology. So when geneticists turned to microorganisms as systems of choice for the problems they wished to study, it is not surprising that French contributions were at the forefront of the new work. Yet such considerations do not suffice to resolve our problem. What needs to be explained is how the junction between genetics and microbiology come to pass. And the answer to this question is not one-sided; in particular, it cannot be provided only by starting from the side of genetics. Formulated in a more conceptual manner, the question becomes: How did the transformation of a problematique of contagion to a problematique of heredity come about in France? Practically speaking, this question concerns the change in the status of microbiology that took place between 1920 and 1940: how did a medical discipline, traditionally confined to institutes of applied research, acquire its new status as an instrument at the disposition of general biology and, in particular, of the science of heredity? How did microbes and viruses, but also phagocytes, antibodics, ctc., ccase to bc investigated simply for their own sake or for their specific role in infection? How did they become indispensable materials for the study of the general characters of living matter, and, most particularly, for the study of the nature of heredity?

This complex question provides a convenient framework for understanding the work of some of the Pasteurians on growth factors in microorganisms and on the nature of the bacteriophage during the twenties and thirties. In both cases, a problem of contagion was gradually metamorphosed into something very close to a general inquiry into heredity, in absolute independence from any Mendelian practice.

The work of André Lwoff on growth factors in protozoa and bacteria is relatively well known to historians. It will be sufficient here to recall the principles on which it was organized and its bearing on our problem. Lwoff began his career by examining evolutionary loss of function, and of such morphological constituents as kinetosomes, in ciliate protozoa..$^{54}$ Partly as an

59. Lwotf's synthesis of this work may be found in Recherches sur la nutrition des Protozoaires (Paris: Masson, 1932). 
outgrowth of this work, from 1920 to 1942 Lwoff patiently demonstrated that protozoa and bacteria (whether parasitic or free-living) have nutritional requirements (for vitamins and growth factors) that are similar to those of the higher animals. ${ }^{(1)}$ In this process, Lwoff put forward a crucial argument in favor of the biochemical unity of all living beings.

Lwoff's aims were primarily physiological; one practical result of interest to us was the creation of a Department of Microbial Physiology under his direction at the Pasteur in 1938. By the time that department was established, Lwoff was using "mutants" as a tool for identifying the steps at which metabolic processes were affected by vitamin deficiencies. The characterization of these "mutants" was independent of any hypothesis about the nature of inheritance in microorganisms. Nonetheless, the work on growth factors had great impact on those geneticists who knew it and who were ready to turn to biochemistry.

One such was George Beadle, who worked with Ephrussi in Paris and Pasadena from 1935 to 1937. Another was Monod, a student of Teissier's (and, like his teacher, a central figure in the Resistance), who was Ephrussi's collaborator during the latter's stay in Pasadena in 1936. To put it briefly, in spite of the fact that this phase of Lwoff's career revealed nothing about the mode of inheritance among microorganisms, it provided geneticists with crucial information: it offered them what proved to be a decisive characterization of phenotypes that are inherited in all living beings, and it gave them techniques for further investigations into these matters. In this respect, Lwoff provided tools for the analysis of the physiological consequences of mutations, together with some of the concepts required to carry out the program of physiological genetics. The need to carry such a program to fruition had long been recognized by geneticists, but, confined to the biological materials, concepts, and techniques available to them before 1940, they had achieved only limited success in executing that program.

Let us turn now to the long tradition of research on bacteriophage. The beginnings of this work are well known - the parallel discoveries of F. W. Twort and Félix d'Hérelle. Some of the outcomes are also familiar - those of Max Delbrück, the phage group, and Lwoff again on lysogeny. ${ }^{61}$ But the strange path by

60. Summarized in A. Lwoff, L'évolution physiologique. Étude des pertes de fonctions chez les microorganismes (Paris: Hermann. 1943). This book contains a full bibliography.

61. The beginnings of this story are usefully sketched from an orthodox perspective in chap. 1 of G. Stent, Molecular Biology of Bacterial Viruses (San 
which a problem of viral contagion came to be a central problem in the modern theory of heredity is less well known. The work of the Pasteurians shows that this was a real metamorphosis and not simply an accidental meeting of disparate traditions.

In 1915 Félix d'Hérelle, a Canadian researcher employed by the Pasteur Institute, observed a spontaneous lysis in colonies of dysenteric bacilli. This lysis was transmissible by contact, and it was brought about by a filtrable agent much smaller than the bacteria. D'Hérelle interpreted the phenomenon as caused by a virus or an ultramicrobial parasite of the bacteria. ${ }^{62}$ The same year Twort, in England, made a similar observation on cultures of micrococcus. He refused to choose among the different hypotheses he proposed - virus, bacteria, protozoa, bacterial enzyme $^{6.3}$ - and did not direct his subsequent research to this aspect of the subject. However, the "Twort-d'Hérelle phenomenon" ${ }^{64}$ prompted intense experimental investigation in the Pasteur Institutes of Paris and Brussels, in an atmosphere of sharp internal competition..$^{65}$

On one hand, there was the "parasitic theory" of d'Hérelle. D'Hérelle relied upon the fact that the lytic agent could be cultivated; this meant that it was a "living organism," able to destroy bacteria and use them. For this reason, he proposed the name of "Bacteriophage," which appeared in 1918 as the name of a theory. ${ }^{66}$ On the other hand, there was the theory of "transmis-

Francisco: Freeman, 1963). The definitive establishment of the existence of lysogenic strains of bacteria by 1925 and the gradual uncovering of the differences (and their importance) between lytic and lysogenic strains are reviewed at pp. 273-280 of A. Lwoff, "Lysogeny," Bacteriol. Rev., 17 (1953), 269-337.

62. F. d'Hérelle, "Sur un microbe invisible antagoniste des bacilles dysentériques," Comp. Rend. Acad. Sci., 165 (1917), 373-375.

63. F. W. Twort, "An Investigation on the Nature of the Ultramicroscopic Viruses," Lancet, (2), 189 (1915), 1241-43.

64. For two different accounts of this terminology, see Stent, Molecular Biology, pp. $11 \mathrm{ff}$., and A. Delaunay, L'Institut Pasteur des origines à nos jours (Paris: France-Empire, 1962), pp. 199 ff.

65. The present discussion is based primarily on an examination of Frenchlanguage sources. There is important work in English, German, and Italian that should be examined in order to gain a comparative perspective. Such a study is, however, beyond the scope of the present paper. The best single source for such a discussion covering the work of the Wollmans is probably Lwoffs "Lysogeny," esp. pp. 276-279. Added in proof: Since this was written, Charles Galperin has published his excellent article, "Le bactériophage, la lysogénie, et son déterminisme génétique," Hist. Phil. Life Sci., 9 (1987), 175-224.

66. See Ph. d'Hérelle, "Technique de la recherche du microbe filtrant bactériophage (Bacteriophagum intestinale)," Comp. Rend. Soc. Biol., 81 (1918), 1160-62, and the four following articles, all published in vol. 83 (1920) of that 
sible autolysis," defended by researchers from the Pasteur Institute in Brussels. It was proposed by the immunologist Jules Bordet (who had recently been awarded a Nobel Prize), in association with Michel Ciuca. ${ }^{67}$ Bordet's theory stated that the transmissible lysis was due, not to a living being, but to a "hereditary nutritive vitiation." Bordet and Ciuca claimed that the hereditary vitiation acted on "intracellular factors" able to "multiply" autonomously inside the bacteria; these factors were diffusible in the extracellular medium and could, therefore, transfer the modification to normal cells, which in turn bequeathed it either to their descendants by division, or to other cells by lysis and contagion. This theory was bascd on the observation that bacteria are able to acquire a partial resistance to the lytic agent so that the lysis can disappear for several generations and appear again in the descendance. This is why Bordet and Ciuca characterized the phenomenon as a "hereditary AND contagious vitiation": it was transmitted both from mother-cell to daughter-cell and by the culture medium.

In the same year, 1920, another young Pasteurian, named Eugène Wollman, supported the theory of Bordet and suggested that it should be united with Darwin's theory of pangenesis. Invoking other phenomena of horizontal transmission of characters between bacteria, he proposed the general term of "paraheredity." The phenomenon of contagion described by d'Hérelle had become a phenomenon of "infectious heredity," with two dimensions of inheritance - "vertical" and "horizontal." 68

The controversy between the Pasteur Institutes of Paris and Brussels over the nature of the phenomenon lasted more than twenty years. But, in the French-speaking world at least, Eugène Wollman gradually came to be recognized as the experimenter and the theoretician able to integrate the two antinomic aspects of the Twort-d'Hérelle phenomenon - namely, the particulate character of the infectious agent, supporting the viral interpretation, and the hereditary nature of lysogeny. ${ }^{69}$ Wollman was the one who

same journal: "Sur la culture du mircrobe bactériophage," "Sur la nature du principe bactériophage," "Sur la résistance des bactéries à l'action du microbe bactériophage," and "Sur le microbe bactériophage." These titles alone are sufficient to give the flavor of d'Hérelle's point of view,

67. J. Bordet and M. Cuica, "Le bactériophage de d'Hérelle, sa production et son interprétation," Comp. Rend. Soc. Biol., 83 (1920), 1296-98.

68. E. and E. Wollman, "À propos de la note de MM. Bordet et Cuica (Phénomène de d'Hérelle, autolyse transmissible de J. Bordet et M. Cuica, et hypothèse de la pangenèse de Darwin)," Comp. Rend. Soc. Biol., 83 (1920), 1478-79, and "Sur le phénomène de d'Hérelle," ibid., 84 (1921), 3-5.

69. Of particular importance is a series of six articles in the Annales de 
introduced the idea that the phenomenon has two phases..$^{70} \mathrm{He}$ characterized one of these as a lysogenic phase, in which the lytic factor is inactive, but is reproduced at the same rhythm and in the same quantity as the bacteria. The reproduction is "true to type," as Wollman said in English, noting that this is "the very signature of hereditary phenomena." ${ }^{71}$ The other phase is the phase "bacteriophage," in which the factor is active and identifiable by physical and immunological means. But the initiation of this phase suggests a parallel with the "theory of hereditary factors" (genetics): "The individualization of lysogenic factors is not without analogies to the cellular processes in which one sees the supports of hereditary characters being individualized at the moment of cell division." 72 From these considerations, Wollman was led to the extraordinary conclusion of his 1938 study written, it should be recalled, before phage had been microscopically visualized ${ }^{73}$ and before there was any question of bacterial or viral genes:

The bacteriophage behave, in our mind, just as cellular characters, as lysogenic hereditary factors. The facts put forward in the present memoir, which complete what was previously known about the numerical relations between bacteria and bacteriophage, appear to fit well with this way of seeing the matter ... [The whole series of observed facts] can

l'Institut Pasteur: namely, E. Wollman, "Recherches sur la bactériophagie (Phénomène de Twort-d'Hérelle)," Ann. Inst. Pasteur, 39 (1925), 789-832; idem, "Recherches sur la bactériophagie (phénomène de Twort-d'Hérelle), deuxiéme mémoire," ibid., 41 (1927), 883-918; E. and E. Wollman, "Recherches sur le phénomène de Twort-d'Hérelle (bactériophagie), troisième mémoire," ibid., 49 (1932), 41-74; "Recherches sur le phénomène de Twortd'Hérelle (bactériophagie ou autolyse hérédo-contagieuse), quatrième mémoire," ibid., 56 (1936), 137-164; and "Recherches sur le phénomène de Twortd'Hérelle (bactériophagie ou autolyse contagieuse), cinquième mémoire," ibid., 60 (1938), 13--57; and E. Wollman and A. Lacassagne, "Recherches sur le phénomène de Twort-d'Hérelle, sixième mémoire: Évaluation des dimensions des bactériophages au moyen des rayons X," ibid., 64 (1940), 5-39.

70. E. and E. Wollman, "Cinquième mémoire," p. 52.

71. Ibid., p. 51.

72. Ibid.

73. It should be noted that $M$. Schlesinger had managed to visualize phage particles as bright points in the dark-field microscope in 1933; cf. "Beobachtung and Zahlung von Bakteriophagenteilchen im Dunkelfeld. Die Form der Tcilchon," Z. Hyg. Infektionsk., 115 (1933), 774-775. The number of particles was roughly comparable to those obtained by a variety of indirect assays. But the issue of the viral and particulate character of the phenomenon was not yet considered to have been definitively established by all of the disputants. 
be interpreted satisfactorily in the theory of hereditary factors [i.e., as the Wollmans explicitly note in the next paragraph, the theory of genes]. ${ }^{74}$

This last parenthetical addition marks a major step, though its fruition was delayed by the war and, tragically, by the Wollmans' deaths at the hands of the Nazis.

What should we conclude regarding Lwoff's and Wollman's research at the Pasteur between the wars? In each case, we find a microbiologist deprived of Mendelian culture advancing to the threshold of what will come to be called "molecular genetics." Their work was of direct influence during the period after the war. In this regard, it is worth noting that Salvador Luria made his first statistical study on phage under the direct influence of Wollman in 1938, when he was in Paris. ${ }^{75}$ Monod's work on enzyme adaptation was begun under Lwoff's influence in Teissier's laboratory at the Sorbonne, but was carried out from 1943 on in Lwoff's Department of Microbial Physiology. ${ }^{76}$ And Lwoff himself, when

74. E. and E. Wollman, "cinquième mémoire," pp. 52-53. Lwoff's appendix to the "quatrième mémoire" of 1936 ("Remarques sur une propriété commune aux gènes, aux principes lysogènes et aux virus des mosaïques," pp. 165-170) makes it clear that he and Wollman had discussed various "factorial conceptions of the lysogenic principle" (p. 165), including the famous passage in H. J. Muller's Croonian Lecture ("Variation Due to Change in the Individual Gene," Amer. Nat., 56 [1922], 32-50) suggesting that the substance responsible for the d'Hérelle phenomenon fits the definition of a gene. Wollman arrived at such views, however, from the analysis of lysogeny and of others' work on bacteriophage, not from research in genetics. The examination of the regulation of lysogeny from this perspective led Lwoff and Wollman to speculate on the distinction between genes as "induccrs" ["inductcurs"] and enzymes as catalysts. Lwoff's text documents (e.g., p. 168) that they were already seeking as of this early date to account for the difference between "constitutive" and "adaptive" enzymes by reference to the effects of permanently active vs. inactive (but activatable) inducers (genes). This prefiguring of the pathway from lysogeny to gene regulation, later elaborated in the Pasteur by Jacob, Lwoff, Monod, and Wollman fils, deserves further exploration.

75. S. Luria, "Sur l'unité lytiquc du bactériophage," Comp. Rend. Soc. Biol,, 130 (1939), 904-908. The object of this study was to determine, by means of statistical methods, whether a single phage was sufficient to produce bacterial lysis. Although Luria worked directly with Raymond Latarjet at the Institut du Radium in the laboratory of Fermont-Lebesque, the work was carried out in collaboration with Eugène Wollman. See also E. Wollman, S. Luria, and F. Holweck, "Effect of Radiation on Bacteriophage C16," Nature, 145 (1940), 935-936.

76. See H. F. Judson, The Eighth Day of Creation (New York: Simon and Schuster, 1979), pp. 358 ff., for a brief account of this work and the circumstances involved. 
he came to study lysogeny in genetic terms with Élie Wollman, Eugène's son, was setting out to meet a challenge thrown down to him and Monod by Max Delbrück at the 1946 Cold Spring Harbor Symposium: Delbrück maintained that all the work on lysogeny was mistaken, an artifact of unrecognized contamination of the bacterial stocks or of similar experimental problems. ${ }^{77}$ Seen in this perspective, the subsequent work on lysogeny in the Pasteur, fairly well known to contemporary readers - and, indeed, most of the work of the Pasteurian school of molecular genetics from 1945 to 1960 - should not count simply as some sort of deepening articulation of a Mendelian paradigm. The sources on which the Pasteurian school drew are obviously extra-Mendelian. Extra-Mendelian, but not anti-Mendelian.

\subsection{The Physiological Genetics of Boris Ephrussi, 1935-1938}

The second major source of the French school of molecular genetics is to be found in Boris Ephrussi's work on the physiology of gene action in the mid-thirties, at the Institut de Biologie physico-chimique. ${ }^{78}$ Ephrussi's case is apparently completely different from that of the Pasteurians. Having spent 1934-1935 as a postdoctoral fellow in genetics at $\mathrm{Cal}$ Tech, Ephrussi did not hesitate to present himself as a (Mendelian) geneticist. Nevertheless, the experimental work with Beadle on the pigmentation of the Drosophila eye is highly atypical from a Mendelian point of view. Ephrussi's methodology, although employed earlier by the Kühn school in Germany ${ }^{79}$ was based on the techniques of causal embryology and was foreign to the usual practices of the geneticists of the time; ${ }^{80}$ this is why his contribution yielded a genuine

77. Cf. J. Monod, "Du microbe à l'homme," in Of Microbes and Life, ed. J. Monod and E. Borek (New York and Paris: Columbia University Press, 1971), p. 7.

78. Our views on Ephrussi have been influenced by the work of Jan Sapp, particularly chap. 5, "Boris Ephrussi, Nucleo-Cytoplasmic Relations, and the Institutional Strategy of French Genetics, 1945-1953," of Beyond the Gene: Cytoplasmic Inheritance and the Struggle for Authority in Genetics (New York: Oxford University Press, 1987). This chapter is the best secondary source on Ephrussi known to us.

79. The general techniques had been elaborated in an important series of studies on Ephestia by A. Kühn's group (including E. Caspari and E. Plagge); see below, $\mathrm{n} .93$, for references and further discussion.

80. In his referee's report on this paper, Will Provine points out that the work of E. B. Ford and Julian Huxley on the shrimp Gammarus (e.g., "Mendelian Genes and Rates of Development in Gammarus chevreuxi," Brit. J. Exp. Biol., 5 [1927], 112-134, or "Genetic Rate-Factors in Gammarus," Arch. Entwicklungs- 
synthesis. But a synthesis of what and what exactly? We must be cautious here, because the usual references to Ephrussi's work on Drosophila eye pigments sound like a foundation legend, projecting the eventual solution of the problem onto the founders of the labor.

The classical presentation says that Ephrussi and Beadle laid the first stones of the future edifice of biochemical genetics. On such a view, the research on the synthesis of the pigments of the Drosophila eye were straightforward anticipations of Beadle and E. L. Tatum's work on Neurospora. More precisely, Ephrussi and Beadle had a presentiment of the rule: "one gene - one enzyme." This classical reconstruction is generally accompanied by a diagram supposed to summarize Ephrussi and Beadle's conclusions in the late thirties. ${ }^{81}$

\section{Diagram 1}

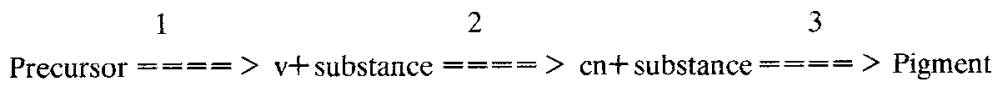

$1,2,3$ : enzymes catalyzing the transformation of the precursor. Homozygous $v$ cannot complete step one, homozygous cn cannot complete step two. $v$ : vermilion gene cn: cinnabar gene $\mathrm{v}+$ and $\mathrm{cn}+$ substances: precursors of the pigments produced by the wild type.

This diagram clearly illustrates a metabolic chain in which the successive transformations of a precursor are controlled at each

mech., 117 [1929], 67-79), and especially that of L. Loeb and S. Wright ("Transplantation and Individuality Differentials in Inbred Families of Guinea Pigs," Amer. J. Pathol, 3 [1927], 251-285), could be counted as antecedents within the genetic tradition for Ephrussi and Beadle's collaborative experiments. Although Ephrussi and Wright exchanged papers, as Provine points out, we have found no reference to Lueb and Wright's transplant experiments or to Ford and Huxley's Gammanus papers in Ephrussi's or Beadle's publications of the time. This contrasts sharply with the extensive references to the papers of Kühn's group. The work of the latter clearly served as an explicit model for Ephrussi and Beadle's transplant experiments; the connection to Ford and Huxley or Leob and Wright, in contrast, seems tenuous at best.

81. E.g., A. Danchin, "Physique, chimie, biologie. Un demi-siècle d'interactions (1927-1977)," in Cinquantieme anniversaire de l'Institut de Biologie physico-chimique (Paris: Fondation Edmond de Rothschild, 1977). A similar account is implicit in Judson, Eighth Day, pp. 279 and 610. Variants of this diagram are found in many textbooks. 
step by a diffusible substance - more specifically, by an enzyme. If this account were correct, Ephrussi and Beadle would have accomplished the main tasks required to bring about the synthesis of genetics and biochemistry, and the work of Beadle and T'atum would simply be the culmination of the project set on foot by Beadle and Ephrussi.

But everything in this story is inexact, as is typical in a "myth of the precursor." The striking thing about this particular myth is that it functions over a very short span of time and the same individual is present at both extremities of the historical chain. The diagram, as we will see, can stand as emblem for the inexactness of the myth. All that survives closer scrutiny is the claim that Ephrussi's work on Drosophila constituted a step toward biochemical genetics, for it certainly was not the first step within that field. To put it briefly, what Ephrussi sought to accomplish between 1934 and 1938 was to bring about a synthesis of genetics and embryology. And in this he succeeded.

Ephrussi was born in Russia in 1901. He arrived in France at the age of nineteen and soon became the favorite student of Faure-Fremiet, then recognized as one of the most fertile experimental embryologists in the world. ${ }^{82}$ Under his dircction, Ephrussi initiated two research projects that occupied his entire attention from 1923 to 1933: (1) A classical work in causal embryology, on the first phases of differentiation of the sea urchin egg; as early as 1925, however, a lateral extension of this work led him to discuss Sturtevant's hypothesis regarding cytoplasmic inheritance in Drosophila on an embryological basis. ${ }^{83}$ (2) A series of studies on tissue culture. Alexis Carrel had just gotten the Nobel Prize for Medicine for his pioneering work in this domain; Ephrussi, after stays in Turin and in Berlin (with Emil Fischer at the Kaiser Wilhelm Institute), decided to apply Carrel's medical techniques to the embryological problem of cellular differentiation. These parallel projects resulted in two theses (the normal requirement in France) in $1932 .{ }^{84}$

By that time, Ephrussi was Fauré-Fremiet's assistant in the

82. Interview with René Wurmser, Institut de Biologie physico-chimique, October 1985.

83. A. H. Sturtevant, "Genetic Studies on Drosophila simulans," Genetics, 5 (1920), 488-500: and B. Ephrussi, "Sur le chondriome ovarien de Drosophila melanogaster," Comp. Rend. Soc. Biol., 92 (1925), 778-780.

84. B. Ephrussi: Contribution à lanalyse des premiers stades du développement de l'oetf. Action de la température (Paris: Imprimerie de l'Académie, 1932), and Croissance et régénération dans les cultures des tissus (Paris: Masson, 1932). 
"Laboratory of Experimental Cytology" of the Institut de Biologie physico-chimique (Rothschild Foundation). In practice, FauréFremiet did not come to the laboratory often, and it was commonly called the "Laboratory of Tissue Culture" or "Laboratory of Ephrussi." "5issue culture was then a very new technique; Ephrussi was the only one doing such work in France, and one of very few to do it in the world. It is precisely this laboratory that five years later, in 1937, became the first official laboratory of genetics in France, and one of the best-known places in the world for physiological genetics.

What happened between 1932 and 1937? Before his stay in Pasadena, Ephrussi knew virtually nothing about Mendelian techniques. ${ }^{86}$ Yet in 1933 he published a first note in which he tackled a genetical question for the first time, entitled "On the Lethal Factor in Brachyuric Mice." 87 This study investigated the underlying causes for the lethality of three mutations that were lethal in homozygotes. Ephrussi approached the problem as an embryologist, asking where the action of the genes becomes manifest: at the level of the cell, of the tissue, or of organic correlations. In order to answer this question, he removed several tissues from the embryo before it died and cultivated them in vitro. In all cases (three tissues from each of three different homozygous lethals), the tissues grew without manifesting any observable differences as compared to tissues from a normal embryo. Since the lethal gene was present in all the cells, it followed either that the action of the lethal gene did not express itself in all the cells of the embryos, or that its effect was to alter organic correlations. None of this work depended on making Mendelian crosses.

Shortly afterward Ephrussi received a Rockefeller fellowship for the 1934-1935 academic year to work under Morgan and Burrows at Cal Tech and with Sturtevant at Woods Hole. While at $\mathrm{Cal}$ Tech, he published an article on "The Absence of Autonomy in the Development of the Effects of Certain Deficiencies in Drosophila melanogaster." 88 The study started from Sturtevant's well-known observations on mosaics. Using typically genetic methods, Ephrussi succeeded in obtaining mosaic individuals with certain regions of the body containing an X-chromosome lethal

85. Interview with René Wurmser.

86. Interviews with Mme Ryss-Ephrussi (Ephrussi's first wife) and René Wurmser, October 1985.

87. B. Ephrussi, "Sur le facteur létal des Souris brachyures," Comp. Rend. Acad. Sci., 197 (1933), 96-98.

88. Proc. Nat. Acad. Sci., 20 (1934), 420-422. 
gene that was not present in the surrounding lissues. ${ }^{84}$ The experiment showed that the effect of the lethal gene is suppressed by the genotypically wild-type surrounding tissues. This study is the only one between 1933 and 1937 in which Ephrussi employed classical Mendelian methodology by our definition - that is, performing sexual crosses and analyzing the progeny as part of the experimental protocol. And it is the only one he ever carried out under the supervision of a geneticist (Sturtevant).

By noting the connection between this experiment and the preceding study of lethal mouse embryos, we can establish a direct line between Ephrussi's work in experimental embryology and the new lines of work that he pursued in genetics. It must have been apparent that the transplantation of tissues offered a much more direct means of obtaining what Sturtevant had been looking for during his ten years of work on mosaics, namely, a technique for distinguishing a gene with "autonomous development" from a gene with a "nonautonomous development." (Notice, incidentally, that if the term "expression" is substituted for "development" in such phrases as "autonomous" or "nonautonomous gene development," we obtain the usual vocabulary of modern physiological genetics.)

Once the decision was made to employ the transplantation technique, things went very fast. In 1935 Ephrussi published a new article on the culture of lethal mouse embryo tissues. ${ }^{90}$ It showed that the known lethal genes not only do not affect the survival of isolated tissues in culture, they also do not affect either their proliferation, or their differentiation, both of which were normal.

That fall Ephrussi returned to Paris with George Beadle, who had also been a postdoctoral fellow in Morgan's laboratory. Together they began the famous experiments involving transplantation of imaginal discs fated to become eyes into Drosophila larvae. (While engaged in this collaboration, Ephrussi, who was already well known as an extraordinarily skilled embryologist, thought of Beadle as his student. ${ }^{4}$ ) The aim of these experiments was clearly set forth in the first paper of the series, a note in the Comptes rendus de l'Académie des Sciences in 1935. The objective was to "lay a bridge between causal embryology and genetics":

89. The principle consisted of using a duplication known for its ability to suppress the effect of the lethal gene located on the $\mathrm{X}$-chromosome. This duplication was often lost during mitotic divisions in males.

90. B. Ephrussi, "The Behavior in Vitro of Tissues from Lethal Embryos," $J$. Exp. Zool., 70 (1935), 197-204.

91. Interview with Mme Ryss-Ephrussi. Beadle was the Ephrussis house guest during this period in Paris. 
It is clear $[\ldots]$ that one cannot now seriously hope to deepen the genetics of the frog or the sea-urchin (the classical objects of developmental mechanics) as far as the genetics of Drosophila; one can, however, undertake to apply the methods of causal embryology to Drosophila (a material of choice for genetic studies). ${ }^{42}$

This is precisely what Ephrussi and Beadle did in their collaboration. The principle was to implant imaginal disks from flies either homozygous or heterozygous for particular genes controlling eye pigmentation into the abdominal cavities of flies of known genotypes. These imaginal disks developed into clearly recognizable, though structurally aberrant, eyes. The observations bore both on the eye that developed in the abdominal cavity and on the host's eyes. This allowed the transplanted eye to be used both as a test and as a control. Transplantation of other organs (kidney, ovary, epidermis) also exhibited a variety of effects. The technique could be refined by using soluble extracts, which permitted a study of the "kinetics of development" of the character and titration of the concentrations of the substances involved. Even without employing biochemical techniques, this made it possible to speculate, on the basis of controlled experimentation, regarding the concentrations of "diffusible substances" intervening in the development of pigmentation, and to deduce something about what is "used" and what is "released" by the imaginal disc. ${ }^{93}$

92. B. Ephrussi and G. Beadle, "La transplantation des disques imaginaux chez les Drosophiles," Comp. Rend. Acad. Sci., 201 (1935), 98.

93. Much of this work is parallel to that of the Kühn group. Cf. the following representative pieces: E. Becker, "Extraktion des bei der Mehlmotte Ephestia kühniella die dunkle Ausfärbung der Augen auslösenden Gen-A-Hormons," Naturwissenschaften, 25 (1937), 507; E. Caspari, "Über die Wirkung eines pleiotropen Gens bei der Mehlmotte Ephestia kühniella Z.," Arch. Entwicklungsmech. Org., 130 (1933), 353-381; A. Kühn, "Entwicklungsphysiologischgenetisch Ergebnisse an Ephestia kühniella Z.," Z. induk. Abstam. Vererb., 73 (1937), 419-455; A. Kühn, E. Caspari, and E. Plagge, "Über hormonale Genwirkungen bei Ephestia kühniella, "Ges. Wiss. Göttingen, Nachr. Biol., n.s. 2 (1936), 1-29; A. Kühn and K. Henke, "Genetische und entwicklungsphysiologische Untersuchungen an der Mehlmotte Ephestia kühniella Zeller. 1.-VII. and VIII.-XII." Abh. Ges. Wiss. Göttingen, 15 (1929, 1932), 3-121, 127-219; and A. Kühn and E. Plagge, "Prädetermination der Raupen-augenpigmentierung bei Ephesiia kühniella Z. durch den Genotyp der Mutter und durch arteigene und artfremde Implantate," Biol. Zentralbl., 57 (1937), 113-126. Ephrussi and Beadle were able to exploit two advantages of Drosophila that were not available to the Ephestia workers: (1) Many well-characterized eye-color mutants were available in Drosophila; this allowed the use of a graded series of tester strains for scoring the effects of - and the effects on - various implants. (2) Once 
The results of the work accomplished from 1935 to 1937 can be summarized straightforwardly. ${ }^{94}$ By 1937 the two authors had shown that the "development of pigmentation" required the intervention of "two diffusible substances." The two substances were called the "v+ substance" and the "cn+ substance," in reference to the deficiencies observed in the vermilion and cinnabar mutants. These were the only mutants among the thirty examined that contained genes whose development was "not autonomous." Ephrussi and Beadle's experiments were, in effect, experiments about physiological complementation. They were exclusively based on organ transplantation (no sexual crosses). The experiments led them to conclude that the two "diffusible substances" were part of a metabolic chain. The figure that they actually employed was the following:

\section{Diagram 2}

$$
*===>\mathrm{v}+\text { substance }===>\mathrm{cn}+\text { substance }
$$

In the earliest studies the place of the * was occupied by "cat substance." In all of these diagrams, there was never anything after "cn+ substance," not even an arrow.

Ephrussi and Beadle recognized that the vermilion and cinnabar mutations affected sequential metabolic steps (the formation of the $\mathrm{v}+$ and cn+ substances), they had the opportunity to dissect a developmental pathway in greater detail than the Ephestia workers since, as it turned out, in spite of the close parallels between the two systems, formation of the v+ but not the cn+ substance was blocked in Ephestia.

94. We shall not list the entire series of articles. What follows is a representative sample: G. Beadle and B. Ephrussi, "Transplantation in Drosophila," Proc. Nat. Acad. Sci., 21 (1935), 642--646; G. Beadle and B. Ephrussi, "Différenciation de la couleur cinnabar chez la Drosophile," Comp. Rend. Acad. Sci., 201 (1935), 620-621; B. Ephrussi and G. Beadle, "La transplantation des disques imaginaux chez la Drosophile," ibid.. pp. 98-100; B. Ephrussi and G. Beadle, "Sur les conditions de l'autodifferenciation des caractères mendéliens," ibid., pp. 1148-50; G. Beadle and B. Ephrussi, "The Differentiation of Eye Pigments in Drosophila as Studied by Transplantation," Genetics, 2I (1936), 76-86; G. Beadle and B. Ephrussi, "Development of Eye Colors in Drosophila: Transplantation Experiments with Suppressor of Vermilion," Proc. Nat. Acad. Sci., 22 (1936), 536-540; B. Ephrussi and G. Beadle, "A Technique for Transplantation for Drosophila," Amer. Nat., 70 (1936), 218-225; G. Beadle and B. Ephrussi, "Development of Eye Colors in Drosophila: Diffusible Substances and Their Interrelations," Genetics, 22 (1937), 76-86; G. Beadle and B. Ephrussi, "Development of Eye Colors in Drosophila: Pupal Transplants and the Influence of Body Fluid on Vermilion," Proc. Roy. Soc. London ser. B, 122 (1937), 98105; B. Ephrussi and G. Beadle, "Développement des couleurs des yeux chez les 
At the beginning of their joint project, the authors entertained three hypotheses concerning the nature of the diffusible substances. These substances might be

1. metabolic precursors;

2. catalytic substances intervening in the transformation of precursors; or

3. hormones controlling the steps of production of the pigment. ${ }^{45}$

By 1938, when the collaborative experiments with Beadle had concluded, Ephrussi made a definitive choice among these hypotheses (though there are strong indications that he had favored it all along): he opted for the hormonal hypothesis. ${ }^{96}$ The arguments that he put forward are (1) that the substances each controlled a very specific reaction; (2) that they are produced at one place in the organism, but active at another site (or sites); and (3) that they are not species-specific, because, as could be shown experimentally, the substances are active in a great variety of insects. ${ }^{97}$ The result of accepting these arguments for the hormonal hypothesis was to leave the relationship between the metabolic chain involved in producing the "hormones" and the metabolic chain involved in producing the pigments obscure.

At the Institut de Biologic, Ephrussi worked with the in-house chemists (particularly Mme Yvonne Khouvine) in an attempt to establish the chemical identity of the famous substances. They failed. ${ }^{98}$ The problem was solved during the war by Tatum in the

Drosophile: Influence des implants sur la couleur des yuex de l'hôte," Bull. Biol. Fr. Belg., 71 (1937), 54-74; B. Ephrussi and G. Beadle, "Development of Eye Color in Drosophila: Transplantation Experiments on the Interaction of Vermilion with Other Eye Colors," Genetics, 22 (1937), 65-75.

95. Ephrussi and Beadle, "Développement des couleurs des yeux," p. 55.

96. B. Ephrussi, "Aspects of the Physiology of Gene Action" |Lecture delivered at Woods Hole, August 1937| Amer. Nat., 72 (1938), 5-23.

97. E. Becker and E. Plagge, "Vergleich der Ausfärbung bedingenden GenWirkstoffe von Ephestia und Drosophila," Naturwissenschaften, 25 (1937), 809; E. Becker, "Die Gen-Wirkstoffe Systeme der Augenausfärbung bei Insekten," ibid., 26 (1938), 433-441; and B. Ephrussi and M. Harnley, "Sur la présence, chez différents Insectes, des substances intervenant dans la pigmentation des yeux de Drosophila melanogaster,' Comp. Rend. Acad. Sci., 203 (1936), $1028-30$.

98. See for instance, Y. Khouvine, B. Ephrussi, and S. Chevais, "Development of Eye Colors in Drosophila. Nature of the Diffusible Substances; Effects of Yeast, Peptones, and Starvation in Their Production," Biol. Bull., 7 (1938), 425-446. 
United States and, mainly, by Adolf Butenandt in Germany. ${ }^{99}$ The failure is not surprising; the Institut de Biologie employed some of the most illustrious biophysicists (René Wurmser) and chemists (Georges Urbain) of the time - but there was no biochemistry.

This account provides a basis for an assessment of Ephrussi's place in the history of physiological genetics. The need for such a discipline had been recognized from the earliest days of the rediscovery of Mendel, and its foundations had been solidly laid by the work of Cuénot in France, Haldane and Archibald Garrod in England (although the importance of the latter's contribution was not recognized by some workers, including Beadle, until quite late), Castle and Wright in the United States, Goldschmidt in Germany, and many others. In France, Cuénot had formulated the problem when he discovered the involvement of numerous genes in the formation of traits, lethal genes, and various forms of gene interaction. In his work on mouse pigmentation, he had indicated as early as 1905 that genes probably control the formation of enzymes, substrates, and similar products affecting the development and structure of the organism. Garrod provided a direct example in 1908, with his discovery of an "inborn error of metabolism" with a clearcut genetic basis, alcaptonuria. ${ }^{161}$ Wright and Haldane patiently continued along the path opened up by Cuénot in their respective research on animal and plant pigmonts. ${ }^{101}$ The common methodological postulate of this entire tradition was that it is possible to determine the genetic basis of physiological characters. In other words, workers in this tradition applied Mendelian methods in their analysis of characters in the hope of identifying the primary products of genes. The path of their research was, thus, from genes to characters, from genetics to physiology.

Now this is precisely what Ephrussi chose not to do. In fact, he seems to have ignored this tradition at the beginning of his career. Instead of looking for the primary product of gene action, he

99. A. Butenandt, W. Weidel, and E. Becker, "Kynurenin als Augenpigmentbildung auslösendes Agens bei Insekten," Naturwissenschaften, 28 (1940), 6364; E. Tatum and G. Beadle, "Crystalline Drosophila Eye-Color Hormone," Science, 9I (1940), 458; and E. Tatum and A. Haagen Smit, "Identification of Drosophila v + Hormone of Bacterial Origin," J. Biol. Chem., I40 (1941), 575580. Cf. also Ephrussi's review. "Chemistry of 'Eye-Color Hormones' of Drosophila," Quart. Rev. Biol., 17(1942), 327-338.

100. A. Garrod. "Croonian Lectures to the Royal Academy of Medicine: Inlyon Errus of Metabolisin," Lancet, 2 (1908), 1-7. Cf. also idem, Inborn Errors of Metabolism (London: Frowde and Hodder, 1909).

101. Cf. Ch. Galperin, "Un gène - un enzyme," forthcoming in Cahiers Soc: Fran. Hist. Sci., originally presented in May 1985. 
located himself at "the other extremity of the chain of actions connecting the gene to the character." As a consistent embryologist, he examined "the reaction of the cellular protoplasm ... to the stimulus of specific substances that are produced by the genes or controlled by them." 102 So Ephrussi was concerned with differentiation at the very moment when the dominant attitude was to come as close as possible to the gene. He was not interested in beginning from gene dosage (Goldschmidt), position effect (Sturtevant), the mutation process (H. J. Muller), the structure of salivary gland chromosomes (Calvin Bridges), or even biochemistry. As late as 1944, when Beadle's and Tatum's Neurospora work had laid down the foundations of "one gene - one enzyme," Ephrussi continued to think in terms of hormones and of the sorts of analysis of the Drosophila developmental pathways that would have been pursued within the embryological tradition. ${ }^{103}$ This stands out clearly in Figure 1, which is redrawn from a review article of $1942 .{ }^{104}$ The accompanying text in that article provides some of Ephrussi's reasons for caution in abandoning the hormonal interpretation. ${ }^{105}$

102. B. Ephrussi, Génétique physiologique (Paris: Hermann, 1939), p. 6.

103. In 1944 and 1945, Ephrussi published three papers based on work done with Jean Lane Herold at Johns Hopkins University (B. Ephrussi and J. Herold, "Studies of Eye Pigments of Drosophila. I. Methods of Extraction and Quantitative Estimation of the Pigment Components. II. Effects of Temperature on the Red and Brown Pigments in the Mutant Blood (wbl)," Genetics, 29 [1944], $148-175$, and $30[1945], 62-70$; B. Ephrussi, "Studies of Eye Pigments of Drosophila. III. The Heterogeneity of the 'Red Pigment' as Revealed by the Effects of the "White' Alleles and by the Color Changes during Development," ibid., 30 [1944], 70-83). These papers deal primarily with the characterization of, and interrelationships between, the red and brown pigments responsible for eye color in Drosophila. The only significant mention of the mode of gene action in the entire series occurs in the three introductory paragraphs of the first paper, where the $\mathrm{vt}$ and $\mathrm{cn}+$ substances are described as "hormone-like diffusible substances derived from tryptophane and representing intermediate links of the brown-pigment-forming reaction| chain." Earlier work on those substances is characterized as based on the hope of "finding a rather direct relationship between the diffusible substances and the genes controlling their production," and as yiclding "the net rcsult ... that the chain of reactions leading to the formation of brown pigment is now rather well defined." There is no mention of one gene - one enzyme or of Beadle and Tatum's Neurospora work or its results anywhere in the entire series.

104. From B. Ephrussi, "Analysis of Eye Color Differentiation in Drosophila," Cold Spr. Harbor Symp. Quant. Biol., 10 (1942), 47.

105. "I should like to forestall some possible objections to the frequent use I have made of the term hormone as applied to the diffusible substances of Drosophila ... I meant to use the term hormone in the sense of a highly active substance produced in a definite organ, transmitted through the internal medium and affecting in a specific manner another definite organ ... 


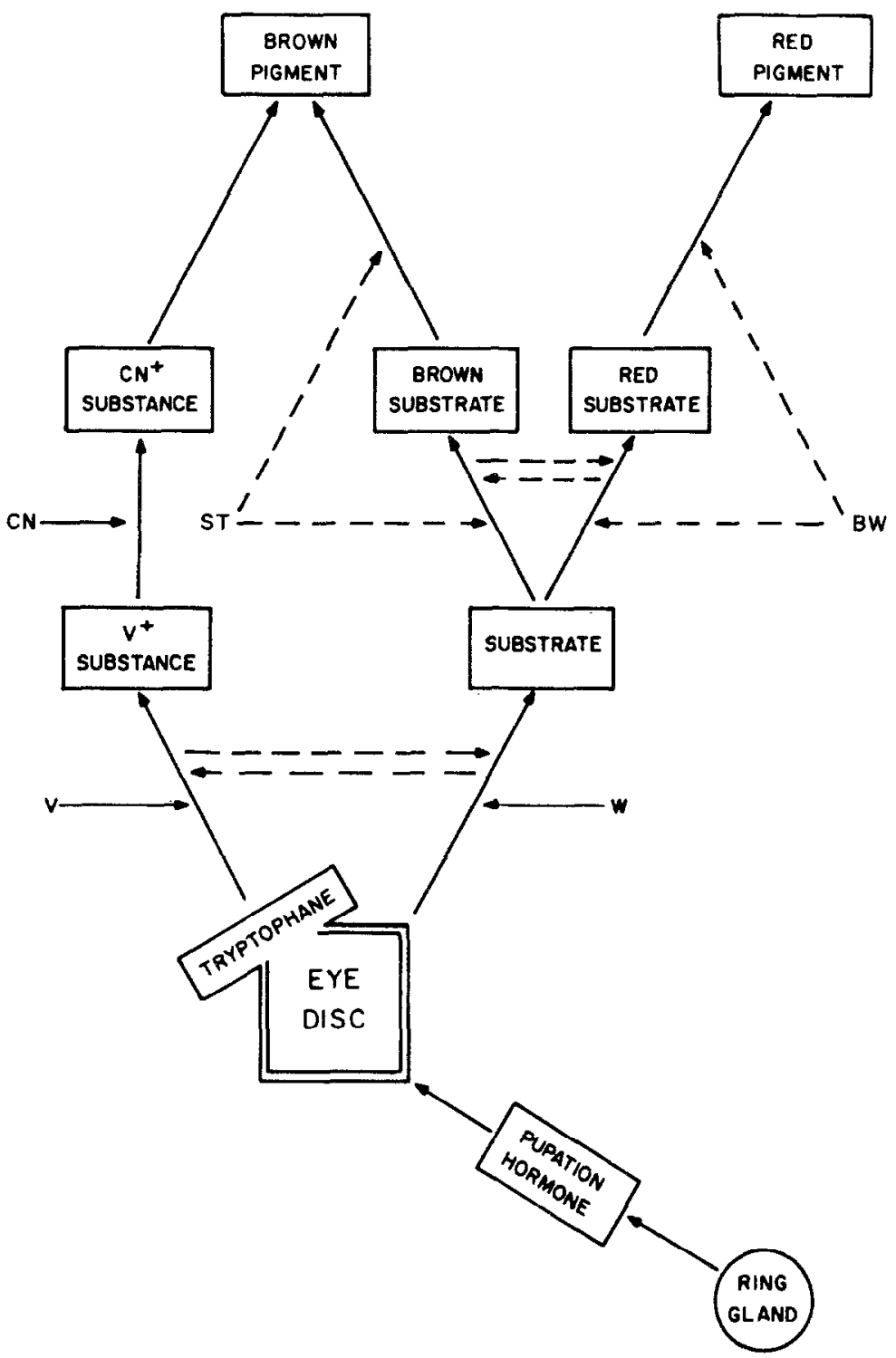

Fig. 1. Schematic representation of eye pigment differentiation in Drosophila. (After B. Ephrussi, "Analysis of Eye Color Differentiation in Drosophila," Cold Spr. Harbor Symp. Quan. Biol. 10 [1942], 47.) Mutations indicated in the figure are: $\mathrm{BW}=$ brown, $\mathrm{CN}=$ cinnabar, $\mathrm{ST}=$ scarlet, $\mathrm{V}=$ vermilion, and $\mathrm{W}=$ white.

"[The Drosophila substances fit this definition, although with two peculiarities.| In the first place, these substances are. most frequently, produced by the same organ which utilizes them. Second, there is usually more than one organ producing them. 
We have now uncovered the fundamental error in the traditional historical presentation of Ephrussi and Beadle: They did not undertake any serious biochemical analysis in their joint work. Nor did they contemplate, postulate, or establish, a specific correspondence between genes and enzymes. From Ephrussi's side, at least, they were not even starting with genes. But they laid down a bridge between genetics and embryology. And, contrary to all expectations and to the spontaneous history passed on to us by the scientists, it was their brief diversion within the field of physiological genetics, their break with the traditional genetic methodology of that field, that prepared the minds of many of their colleagues for what proved to be the long-awaited molecular revolution in genetics.

One moral of this story is that one does not always have the parents one would like to have. Ephrussi himself made great efforts later on to forget his parentage and to present himself as a "molecular biologist" - which is something that he was not during the period we have examined, and probably never was.

To round off our account of Ephrussi, we must add one last point. Remember the great prestige of causal embryology in the French and Belgian universities. In this field, just as in microbiology, there was a climate of open competition with Germany. This climate was of considerable help to Ephrussi in facilitating the reception of the Drosophila work, since the embryological basis of his approach to physiological genetics was one with which traditional French biologists had considerable sympathy. This helps, in turn, to reinforce our claim that causal embryology is the third extra-Mendelian tradition, besides physiology and microbiology, that enters into and helps explain the "miracle" of the late forties and fifties ${ }^{106}$

"While the classical definition of hormones contains only references to the locus of formation, method of transfer and locus of action of a substance, in modern writings the term hormone has often been meant to imply also a reference ... to a mode of action ... [as a] biocatalyst. [Hormones] should merely assist, not participate in, the reaction whose course they affect or control. The substances I have been discussing certainly do take a direct part in the process of pigment formation ... Nevertheless, it remains to be shown directly that kynurenin or the cnt substance is actually a building block in the synthesis of the brown pigment" ibid.).

106. There remains one further tradition whose importance in the history we have been exploring needs close investigation - that of cytology. Caullery, for example, preferred to treat the chromosomal theory as part of the theory of the cell rather than as simply a theory of heredity. And Guyenot was heavily involved in cytogenetics. We hope to explore the role of cytology in this regard in our continuing research on these matters. 


\section{CONCLUSION}

In this study we have examined the reception of Mendelism in France from 1900 to 1940 , and the place of some of the extraMendelian traditions of research that contributed to the development of genetics in France after World War II. Our major findings are:

(1) Mendelism was widely disseminated in France and thoroughly understood by many French biologists from 1900 on. With the notable exception of Lucien Cuénot, however, there were few fundamental contributions to the Mendelian tradition, and virtually none from about 1915 to the midthirties. Prior to 1900 , Cuénot's work was already marked by a striking interest in physiological mechanisms; his physiological preoccupations played a considerable role in his account of the inheritance of coat color and of susceptibility to tumors in mice. His analysis of the roles of the many genes involved in pigment formation was developed with an eye to one of the first models of the metabolic reactions involved. It yielded one of the earliest suggestions that the steps controlled by single genes involve enzymes as the products of genes.

(2) The inflexible structure of the French universities played an important role in discouraging research in genetics and in the failure to train the post-World War I generation in that discipline.

(3) During this period the disciplines of physiology, microbiology, and causal embryology were dominant in French experimental biology. The issues that were most prominent within these disciplines - differentiation and development, regulation of growth and morphology, infection and assimilation - were not easily treated within genetics. The failure of Mendelism to resolve a variety of legitimate explanatory issues to the satisfaction of serious investigators trained in the dominant French disciplines also contributed to the failure of Mendelism to penetrate French science. The violent anti-Mendelian polemics put forward by many of the most committed neo-Lamarckians raised many of the same issues regarding the supposed insufficiency of Mendelism. Cuénot's reluctance to encourage his students to pursue careers in genetics illustrates the compound nature of the resistance. 
Despite the absence of a developed tradition of Mendelian research, a French school of molecular genetics had developed by the 1950s. It flourished outside the university system at the Institut Pasteur, the Institut de Biologie physico-chimique, and the CNRS (though some of its leading figures had university connections), and it was only beginning to enter into university curricula. The most important indigenous research that informed the new tradition was that of Eugène Wollman on "paraheredity" of phage infection and lysogeny, of André Lwoff on the physiology and nutritional requirements of protozoa and bacteria, and the embryologically influenced genetic investigations of Boris Ephrussi. The conceptual and methodological resources of the French school were enriched by this background; a full understanding of the products of the fifties, we believe, requires a proper appreciation of these antecedents. Molecular genetics in France grew out of the Pasteurian tradition of microbiology and the highly developed tradition of causal embryology as modified by Ephrussi. Both of these traditions were extra-Mendelian and not anti-Mendelian, but they both shared a number of the problems and assumptions that were at the center of the extremist resistance to Mendelism. In many respects, then, it is more fruitful to see the entry of French biology into molecular genetics as a development of its microbialphysiological and causal-embryological traditions, coopting the tools and techniques of genetics, rather than the other way around.

\section{Acknowledgements}

Work on this paper was supported by a generous grant from the National Endowment for the Humanities. We are grateful to the Endowment, as also to the Rockefeller Archive Center for a grant-in-aid in support of archival research to one of us (D. Z.). Preliminary versions of the paper were read at the 1985 Summer Conference on History, Philosophy, and Social Studies of Biology and at the 1985 Meetings of the History of Science Society. We are grateful to our discussants and critics on those occasions and to colleagues and friends too numerous to mention for encouragement, criticisms, and suggestions. We are also grateful to Mark Adams, Marjorie Grene, Harry Paul, Muriel Lederman, and William B. Provine for their critiques of our penultimate draft, to Anita Malebranche and Rebecca Stormer for bibliographical help, and to Vanessa Alexander and Christine Duncan for patient and skillful secretarial assistance. 